\title{
Wind Turbines, Public Acceptance, and Electoral Outcomes*
}

\author{
Resul Umit ${ }^{\dagger}$ \& Lena Maria Schaffer ${ }^{\ddagger}$
}

07 January 2022

\begin{abstract}
Despite a widespread public support for wind energy in general, wind turbine proposals attract a considerable amount of public opposition. At a time of political commitments to building more wind turbines for climate risk mitigation, we study the potential causes of this opposition and their electoral effects. Our analysis draws on a survey experiment in Switzerland, where the number of wind turbines will grow from a couple of dozens to many hundreds in the next three decades. We find that exposure to wind turbines increases public acceptance, but this affect does not translate into electoral turnout or vote choice. Moreover, locality or politicisation does not seem to have an effect at all-neither on acceptance nor on electoral outcomes. Our results suggest that voters do not reward or punish political parties for their positions on wind energy, even when turbines might soon be rising in their local area.
\end{abstract}

Word Counts: 148 in abstract, 7,509 in main text, 2,290 in appendix, and 3,818 in pre-registered plan

${ }^{*}$ This manuscript is part of the project 'Beyond Policy Adoption: Implications of Energy Policy on Parties, Publics, and Individuals', funded by the Swiss National Science Foundation (PYAPP1-173642/1). Its design was pre-registered, before data collection, at EGAP (20190903AA). We wish to thank Beatrice Eugster and the participants of the workshop 'Political Economy of Energy Transitions' for comments on previous versions of this manuscript.

${ }^{\dagger}$ Corresponding author. University of Oslo. Email: resuluy@uio.no.

${ }^{\ddagger}$ University of Lucerne. Email: lena.schaffer@unilu.ch. 


\section{Introduction}

The fight against climate change counts on producing more energy from wind in the future. Indeed, many countries are under national and international commitments to drastically increase the share of their renewable electricity production with new wind turbines. For example, if Switzerland, a country with only 37 turbines at the beginning of 2020, is to meet its greenhouse reduction targets, there will have to be hundreds more built in the next three decades. ${ }^{1}$ There are signs that others will follow suit - the countries producing wind energy have recently outnumbered those that do not, with new wind turbines being erected in every region of the world (REN21, 2019).

Successful deployment of wind energy depends on public attitudes which have long puzzled social scientists. On the one hand, there is a widespread public support for wind energy in general. For example, over $70 \%$ of Canadians (Sherren, Parkins, Owen, and Terashima, 2019) and more than $80 \%$ of Americans (Klick and Smith, 2010) are in favour of this energy source. On the other hand, wind turbine proposals attract a considerable amount of public opposition (Firestone and Kempton, 2007; Pasqualetti, Gipe, and Righter, 2002). This opposition not only risks increasing the cost of wind turbine projects or delaying the benefits of transition to renewable energy. It also calls the political feasibility of energy transition into question as politicians might be reluctant to pursue such unpopular climate change policies in the first place (Gärling, 2007).

We know relatively less about the political consequences of wind energy deployment. Energy issues (Jeong and Lowry, 2021; Kuzemko, 2016), and particularly the siting of wind turbines (Bues and Gailing, 2016), have remained largely depoliticised until recently. However, there are signs of change. Jeong and Lowry (2021), for example, show that energy policy is becoming an increasingly politicised issue in the U.S. Congress. Efforts to de- and re-politicise energy issues suggest that policy positions on related policy instruments, such as wind turbines, might have electoral consequences. Indeed, Stokes (2016) shows that there are such consequences at the aggregate level, in terms of electoral turnout and vote shares.

In this article, we examine the causal effect of three factors - project locality, turbine exposure, and

\footnotetext{
${ }^{1}$ Our own calculations. Switzerland produced about 121 GWh electricity with its 37 wind turbines in 2018 (SFOE, 2019), and it is planning to produce about 4,000 GWh per year by 2050 (ARE, 2017). Based on these statistics, meeting its targets would require Switzerland to build around 1,180 new turbines. However, the actual number is likely to be in the hundreds, depending on the expected increases in the efficiency of new wind turbines in the future.
} 
issue politicisation - on electoral turnout and vote choice as well as on public acceptance of wind turbines. The findings are at odds with much of the literature, and indeed with our expectations. Although we find that exposure to wind turbines increases public acceptance, there is no evidence of a relationship between the remaining factors and outcomes. Our analysis draws on an experiment, designed to test how people respond to proposals for new wind turbines. It is based on a random assignment of subjects to one of the eight versions of a vignette - a text with an image about proposals - in a $2 \times 2 \times 2$, full-factorial design. This experiment was part of an online survey, conducted with a nationally representative sample of voting-age population in Switzerland, shortly before the 2019 Swiss federal election.

The contribution of this article is two-fold. First, much of what we know about the public acceptance of wind turbines originates from observational research, unable to establish causal links. With null results from our experimental tests, this study suggests that some of the most conventional findings in the literature, such as the negative attitudes towards local wind turbine proposals, might be spurious relationships. Second, our results might come as a relief to political actors looking to increase efforts to fight climate change. If they are to push for more wind turbines, our results from Switzerland suggest that there will not be electoral consequences, albeit with no rewards either, for their pro-environmental positions.

\section{Literature}

There is a large literature on public attitudes towards energy technologies. Gaede and Rowlands (2018), for example, note that there were at least 857 academic publications in this area by 2015 . Wind energy, and specifically wind turbines, are the focus of many of these publications, and systematic reviews of the related literature are available elsewhere (see, for example, Cashmore, Rudolph, Larsen, and Nielsen, 2019; Hevia-Koch and Ladenburg, 2019; Rand and Hoen, 2017). Here we discuss four aspects that feature prominently in this literature, which we incorporate into our study.

First, many explain the contrast between support for wind energy and opposition to wind turbines with reference to general against local preferences. Unlike the benefits of wind turbines, their costs 
and risks are geographically concentrated, in or around siting locations. As researchers are motivated to understand the local opposition towards wind turbines, much of what we know about public attitudes comes from around sitting locations (Rand and Hoen, 2017). Early studies pointed at the 'not-in-my backyard' (NIMBY) syndrome (Dear, 1992) - that the locals simply do not want to live with turbines in their neighbourhood. Today the scholarly consensus is that there is more to local opposition than locals' distance to wind turbines (Pasqualetti, 2011). For example, some argue that wind turbines damage the locals' connection to geographical places and therefore pose a challenge to their 'place identity' (Devine-Wright, 2009; Wolsink, 2006). Even though some studies report that the local attitudes to wind turbines are in fact positive (Fergen and Jacquet, 2016; Firestone and Kirk, 2019; Hoen et al., 2019; Petrova, 2014), location remains a major aspect of research on public attitudes in this area.

Urban-rural divide is a second aspect. Some scholars view the attitudes towards wind turbine deployments as a conflict of interest, between the electricity-hungry urban residents and the suffering rural communities, where constructions like turbines do not belong to the landscape (Hirsh and Sovacool, 2013). In this sense, wind turbines are seen as an element of 'rural environmental injustice' (Kelly-Reif and Wing, 2016). Evidence from interviews confirms that this view resonates among many residents in rural areas - that they think wind turbines are deployed in rural areas for urban interests, by urban decision-makers (Walker, Mason, and Bednar, 2018; Walker, Stephenson, and Baxter, 2018). It stands to reason, then, if the urban-rural divide features prominently in the debate over public attitudes towards wind turbines (see Rand and Hoen, 2017, p. 139).

Third, in terms of the process of wind turbine deployment, politicisation looms large as an important aspect. In the absence of political contestation, such as under 'authoritarian environmentalism,' evidence shows that policy-makers find it easier to implement environmental policies in general (Gilley, 2012). With contestation, however, comes increased opposition (Bolsen, Druckman, and Cook, 2014; Walker et al., 2018). Walker et al. (2018) find that where the political parties are divided over wind turbines, public opinion is less favourable, especially among people who identify with the party that opposes wind turbines. Accordingly, politicisation can lead to opposition in at least two ways (Walker et al., 2018): (1) by cueing party followers who may otherwise be uninterested, undecided, or supportive and (2) by signalling that it is acceptable to oppose renewable energy, 
which has otherwise strong normative connotations.

Visual exposure to wind turbines is the fourth and final aspect from the literature that guides our study. Unlike many other sources of electricity generation, 'wind turbines, by their very nature, require a highly dispersed and visible distribution, often in attractive and unspoiled areas' (Hirsh and Sovacool, 2013, p. 724). Studies, old and new, show that concerns for the visual impact of wind turbines are one of the main reasons behind public opposition (Álvarez-Farizo and Hanley, 2002; Bishop and Miller, 2007; see, for example, Bush and Hoagland, 2016; Gipe, 1993; Johansson and Laike, 2007; Schäffer, Pieren, Hayek, Biver, and Grêt-Regamey, 2019). However, once wind turbines are built, public support recovers as people are exposed to the finished project (Wolsink, 2007). Research shows that, in fact, a majority of people enjoy seeing wind turbines in their daily life (Mulvaney, Woodson, and Prokopy, 2013), and the acceptability of wind turbines is higher among those who are visually exposed to them than those who are not (Baxter, Morzaria, and Hirsch, 2013; Groothuis, Groothuis, and Whitehead, 2008; Ladenburg, Termansen, and Hasler, 2013).

Despite a large volume of social science studies on wind turbines, the literature also has its limitations. First, as Rand and Hoen (2017) suggest after their review, the literature suffers from selection issues: researchers select one or a small number of - often problematic - wind energy projects to study, using methods that depend on self-selection of respondents. Therefore, after decades of research and hundreds of studies, we are largely unable to establish causal links. For example, Hoen et al. (2019) find that wind turbines lead to changes in demographics; people with positive attitudes move in to the areas around existing wind turbines while those with negative attitudes move away from them, putting a question mark over studies that report improvement of public attitudes towards wind turbines in time or with exposure. Second, the literature is based largely on studies of single factors, such as location or exposure. However, as Boudet (2019, p. 452) argues, understanding 'the reality of public perceptions and response requires examining how [various factors] interact.'

Finally, the literature is also lacking a political science perspective. Do the effects of wind turbine proposals spread to political arena? To our knowledge, there are only two studies that have assessed the political implications of wind turbine proposals. Walker et al. (2018) provide evidence from a small number of people living in two provinces in Canada, suggesting that parties supporting wind turbines suffer electoral losses in areas with turbines but only when the parties opposing 
these developments politicise the proposals. Similarly, Stokes (2016) shows that, again in Canada, electoral turnout increases and government vote share decreases in precincts with, or close to, a wind turbine. Our study will contribute to this emerging strand of literature, with an experiment designed to address the gaps in the literature.

\section{Hypotheses}

A first set of our hypotheses relates to the public acceptance of wind turbine proposals, contributing to a large number of existing studies on this question with experimental tests of causality. Following the frequently reported relationships in the literature summarised in the previous section, we expect that public acceptance (a) decreases if wind turbines are proposed for one's own locality, (b) increases with visual exposure to wind turbines, and (c) decreases with issue politicisation.

Electoral outcomes are the focus of a second set of hypotheses. Do wind turbine proposals, and/or party positions on these proposals, affect electoral turnout or vote choice? Given the link between opposition to siting projects and increased political participation (Mansfield, Van Houtven, and Huber, 2001), we expect that the three factors above have the contrary effect on turnout-locality and politicisation should increase turnout while exposure should decrease it. In terms of vote choice, we hypothesise that when parties politicise wind turbine deployments, voters would be less likely to be neutral, a sign of indifference, towards them-irrespective of party positions on the issue. Whether parties are rewarded or punished, however, should depend on not only their positions but also the remaining two factors (locality and exposure). For example, we expect that parties supporting wind turbines experience vote losses among voters living local to the proposed siting locations and/or those who have not been exposed to the proposed turbines yet.

Finally, we test whether the results differ from rural to urban populations. Here our overall hypothesis is that there are meaningful differences between these sub-groups such that the expected relationship above are stronger for the residents in rural populations than in intermediate and especially in urban populations. 


\section{Data and Design}

Our pre-registered analysis is based on data from an online survey, conducted in Switzerland from 6 to 20 September 2019, with an experimental component. Switzerland, of September 2019, is a particularly advantageous setting for our study. Previously, Swiss citizens have backed the national energy strategy (Energy Strategy 2050) in a referendum, which foresees large increases in renewable energy. However, with only 37 large wind turbines installed at the time (SFOE, 2019), ${ }^{2}$ Switzerland needs to erect hundreds more in the next three decades to meet the target in this strategy. This allows us to study how people react to wind turbine proposals where these structures are rare and few but their arrival is imminent. Second, our survey was in field during the campaign period for the 2019 Swiss federal election, until two days before the first postal votes were cast. This allows us to study the effect of wind turbine proposals on electoral outcomes at a time when these outcomes are about to emerge. Put together, the case selection contributes to the validity of our analysis.

We obtained 4,151 respondents from respondi (www.respondi.com), aiming at a sample that is representative of the Swiss voting-age population in terms of age, gender, and region. In the end, the respondents came from all 26 cantons in Switzerland. Yet, compared to the Swiss voting-age population, our sample was slightly younger (46 years, in comparison with 49). Similarly, the share of females was higher in our sample (54\%) than in the population (51\%). However, because we are interested in establishing cause and effect relationships rather than estimating causal effects for the Swiss population, such differences are less of a concern for our study. For the same reason, for example, we intentionally over-sampled respondents from outside urban areas - to increase the precision of our sub-group estimates for the urban-rural divide. We provide detailed comparisons between our sample and the voting-age Swiss population in the Appendix.

The survey started with a series of questions to measure pre-treatment covariates with regard to demographics (canton, years lived in that canton, commune, gender, birth year, education) and attitudes (worries about climate change, interest in politics, and left-right self placement). We used the question on canton of residence to create the locality factor, as explained below. All remaining covariates were used to adjust our estimates. To do so, we first re-coded (a) the commune variable

\footnotetext{
${ }^{2}$ This number (37) had not changed since 2017 when, in comparison, there were 1,260 wind turbines in Austria, 29,844 in Germany, 6,734 in Italy (IEA, 2019).
} 
as rural, intermediate, or urban according to the classification from the Swiss Federal Statistical Office and (b) the birth year variable in terms of age in 2019.

After the experimental component and outcome measures, we placed an income question at the end of the survey, which also included additional questions for a separate study. The questionnaire and descriptive statistics are in the Appendix.

\subsection{Experimental component}

To be able to test the effect of three factors (locality, exposure, and politicisation) in a single study, we used a factorial survey experiment (Auspurg and Hinz, 2014). The experimental component was based on a random assignment of subjects to one of the eight versions of a vignette, resulting from crossing three factors, each with two levels. We provide the vignette structure below, with a screenshot available in the Appendix.

To increase the amount of electricity generated from renewable sources of energy, there are proposals to place wind turbines in the canton of [Locality: own / different canton], in landscapes similar to the one pictured below.

[Exposure: photograph with / without a wind turbine]

There has been a mixed reaction to these proposals. Some [Politicisation: 'people' / 'political parties, such as the Social Democratic Party of Switzerland,'] support these proposals while other ['people' / 'political parties, such as the Swiss People's Party,'] oppose them.

With Locality, we varied whether the vignette mentioned the name of (a) the respondents' own canton or (b) a different canton as the location of proposed wind turbines. The latter was chosen randomly, among the remaining 25 cantons, after respondents' own canton was excluded.

The vignette did not only have a text but also a photograph. Accordingly, Exposure varied whether there was a wind turbine in the photograph or not, as shown in Figure 1. The photograph with 
the wind turbine is the original, taken in the canton of Lucerne in Switzerland. We have digitally removed the turbine from this landscape, and the resulting photograph is the one on the right in Figure 1.

Finally, with Politicisation, we varied whether the vignette mentions that there was a disagreement among (a) the people or (b) political parties about wind turbine proposals. This follows the experimental design in Boudreau and MacKenzie (2014). We used the two mainstream parties with clear positions on wind energy: the Social Democratic Party of Switzerland, which supports wind turbine proposals, and the Swiss People's Party, which opposes them. They had been the largest two parties in Switzerland at least since 1999, and this did not change in the 2019 election that followed our experiment.
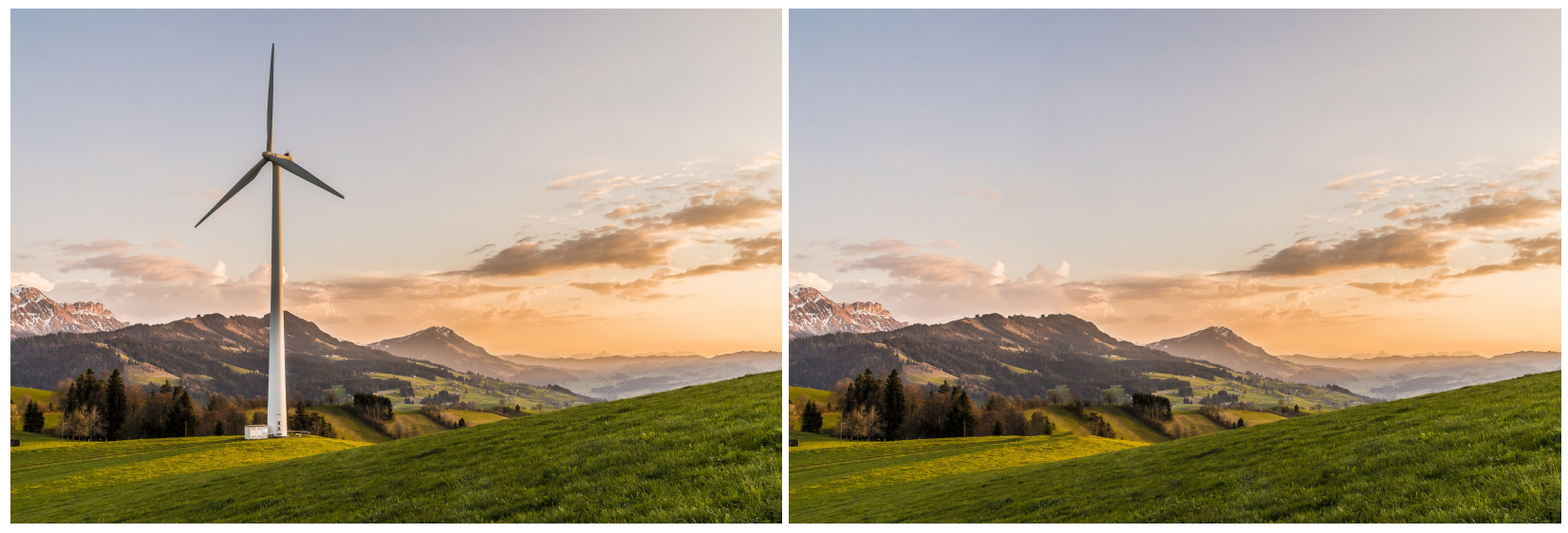

Figure 1: Two versions of a landscape in the canton of Lucerne, Switzerland. On the left, the original photograph of a wind turbine in the commune of Entlebuch. On the right, the digitally altered version without the turbine.

As a factual manipulation check on respondent attentiveness to the experimental component (Kane and Barabas, 2019), the survey included one question, the subject of which was randomly varied: (a) the number of turbines in the photograph, (b) proposed location of the turbines, and (c) the actors mentioned as having disagreements over the proposals. With one correct answer category among four choices, including a category for 'Don't know', this is a relatively challenging manipulation check. Nevertheless, on average, $70 \%$ of respondents answered their question correctly, suggesting that most respondents read and understood their vignette. ${ }^{3}$

Table 1 lists the post-treatment measures that we analyse as dependent variables. For Acceptance,

\footnotetext{
${ }^{3}$ Those who failed the check are included in the analyses below. The results are robust to excluding them.
} 
Turnout, Supporting Vote, and Opposing Vote, we recode the 'Don't know' answers as missing, otherwise keeping the coding scheme of the related survey questions provided in the Appendix. For Neutrality, our coding scheme is the number of questions that subjects answer as 'Neither likely not unlikely' or 'Don't know.' We limit the analysis of the post-treatment measures of electoral outcomes - Turnout, Supporting Vote, Opposing Vote, and Neutrality - to those subjects who are eligible to vote in the 2019 Swiss federal elections.

Table 1: Outcome Measures

\begin{tabular}{|c|c|c|c|}
\hline Outcome & Question(s) & Range & Detail \\
\hline \multirow[t]{2}{*}{ Acceptance } & Do you support or oppose & {$[1,5]$} & Recode 'Don't know' \\
\hline & these wind turbine proposals? & & as missing \\
\hline \multirow[t]{4}{*}{ Turnout } & The Swiss federal election is & {$[1,5]$} & Recode 'Don't \\
\hline & being held on 20 October & & know' as missing \\
\hline & 2019. How likely is that you & & \\
\hline & will vote? & & \\
\hline \multirow[t]{5}{*}{ Neutrality } & How likely is it that you will & {$[0,2]$} & Count the number \\
\hline & vote for ... (1) the Social & & of questions \\
\hline & Democratic Party of & & answered as \\
\hline & Switzerland? ... (2) the & & 'Neither...' or \\
\hline & Swiss People's Party? & & 'Don't know' \\
\hline \multirow[t]{3}{*}{ Supporting Vote } & How likely is it that you will & {$[1,5]$} & Recode 'Don't know' \\
\hline & vote for the Social Democratic & & as missing \\
\hline & Party of Switzerland? & & \\
\hline
\end{tabular}




\begin{tabular}{rcrr}
\hline Outcome & Question(s) & Range & Detail \\
\hline Opposing Vote & How likely is it that you will & {$[1,5]$} & Recode 'Don't know' \\
& vote for the Swiss People's & & as missing \\
& Party? & \\
\hline
\end{tabular}

\section{Results}

Our analysis is based on three estimates of interest: (1) average marginal component effects (AMCEs), (2) conditional marginal means (CMMs), and (3) average component interaction effects (ACIEs).

In a factorial survey experiment such as ours, one causal quantity of interest is AMCEs (Auspurg and Hinz, 2014; Hainmueller, Hopkins, and Yamamoto, 2014). These measure the effect of a given level of a factor (e.g., Locality: own canton) on an outcome (e.g., Acceptance), compared to a baseline level of that factor (i.e., Locality: different canton), averaged across all other factors (e.g., Exposure, but also, where available, covariates) and across all respondents. Here in the main body of the text, we summarise the results from ordinal least square regressions in Figure 2, from models with or without covariates. The results remain the same if we use ordered logistic (for Acceptance and Turnout) or Poisson (for Neutrality) regressions. We report these alternative specifications (Table A4) as well as the complete OLS results (Table A2) in the Appendix.

Overall, the effects are substantively small and statistically insignificant in most cases. Here are some example point estimates from models that include control variables, with $95 \%$ confidence intervals in square brackets. We find that if wind turbines are proposed for respondents' own canton, this leads to a 0.03 point decrease [-0.1, 0.03] in Acceptance, over a five-point scale, in comparison with proposals for any other canton. On the same scale, these local proposals increase Turnout by 0.08 points $[-0.004,0.16]$ while decreasing Neutrality by 0.03 points [-0.08, 0.02]. However, none of these effects are statistically significant. For Politicisation, all three estimates are positive, but the point estimates are even smaller, and the $95 \%$ confidence intervals around these estimates include zero as well. These results suggest that, contrary to our expectations, local or politicised wind 

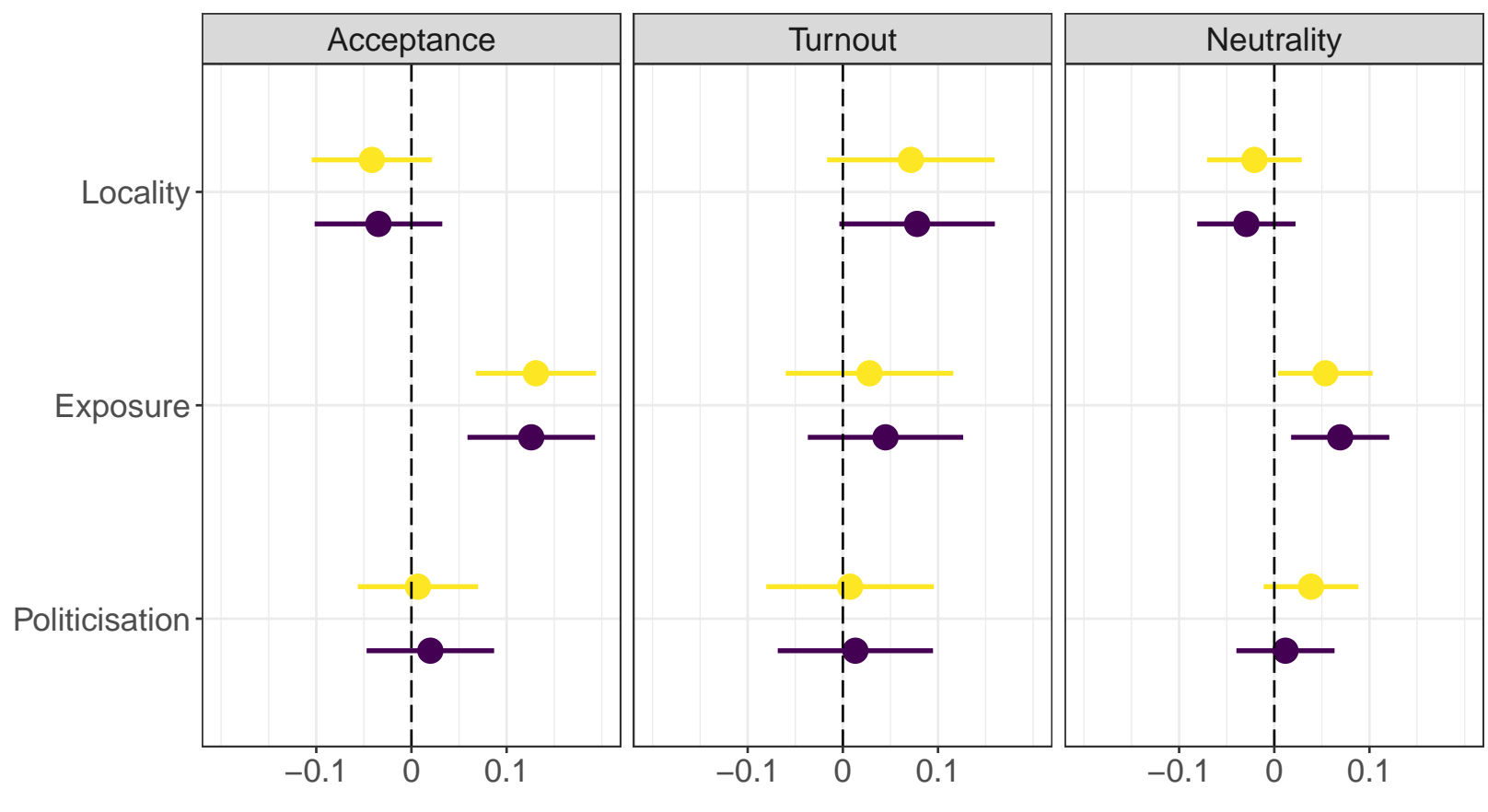

Estimated AMCE

Models ... without with ... control variables

Figure 2: Average marginal component effects. Note: The factors are coded as own $=1$ vs. different $=0$ canton (Locality), photographs with $=1$ vs. without $=0$ a wind turbine (Exposure), and politicised $=1$ vs. unpoliticised $=0$ arguments (Politicisation) . 
turbine proposals do not have meaningful effects on public acceptance or electoral outcomes.

The results are different for Exposure. In comparison to the one without the wind turbine, we find that the photograph with the turbine increased Acceptance and Neutrality in the experiment. We observe a statistically significant, 0.13 point change [0.06, 0.19] in Acceptance as a direct result of variation in the photograph. While there was no comparable effect on Turnout, Exposure increased Neutrality as well-by 0.07 points $[0.02,0.12]$ over a three-point scale. Therefore, we find some evidence that exposure to wind turbines increase public acceptance and leads to meaningful changes in electoral outcomes. This is in line with the existing evidence on the positive effects of visual exposure to wind turbines.

\subsection{Sub-group Analysis}

To test the claim that attitudes to wind turbines differ from rural to urban populations, we conduct a sub-group analysis for respondents from three classes of Swiss communes: rural, intermediate, and urban. Here we will follow Leeper, Hobolt, and Tilley (2020), and conduct our analysis over CMMs, which measure the differences in AMCEs between subgroups of respondents. Our overall hypothesis is that there are meaningful differences between these sub-groups such that the effects are larger for the residents in rural communes than in intermediate and especially in urban communes.

Figure 3 visualises the differences between the preferences of respondents from urban and intermediate areas in comparison with respondents from rural areas. Hence, for example, if urban respondents were significantly more likely to accept wind turbines in their own canton than rural respondents, we would see positive estimates for Locality in the upper left facet in the figure. We do not find such differences between the subgroups: again, the estimated differences are small and the confidence intervals include zero. The only exception is the estimate for the difference between urban and rural areas, for the effect of Exposure on Turnout. However, this positive difference appears only if we do not control for covariates, and once we do, it completely disappears.

\subsection{Interaction effects}

The effect of a given level of a factor on an outcome could depend on the levels of another factor. For example, if there is an effect of Locality or Exposure on vote choice, this should depend on 

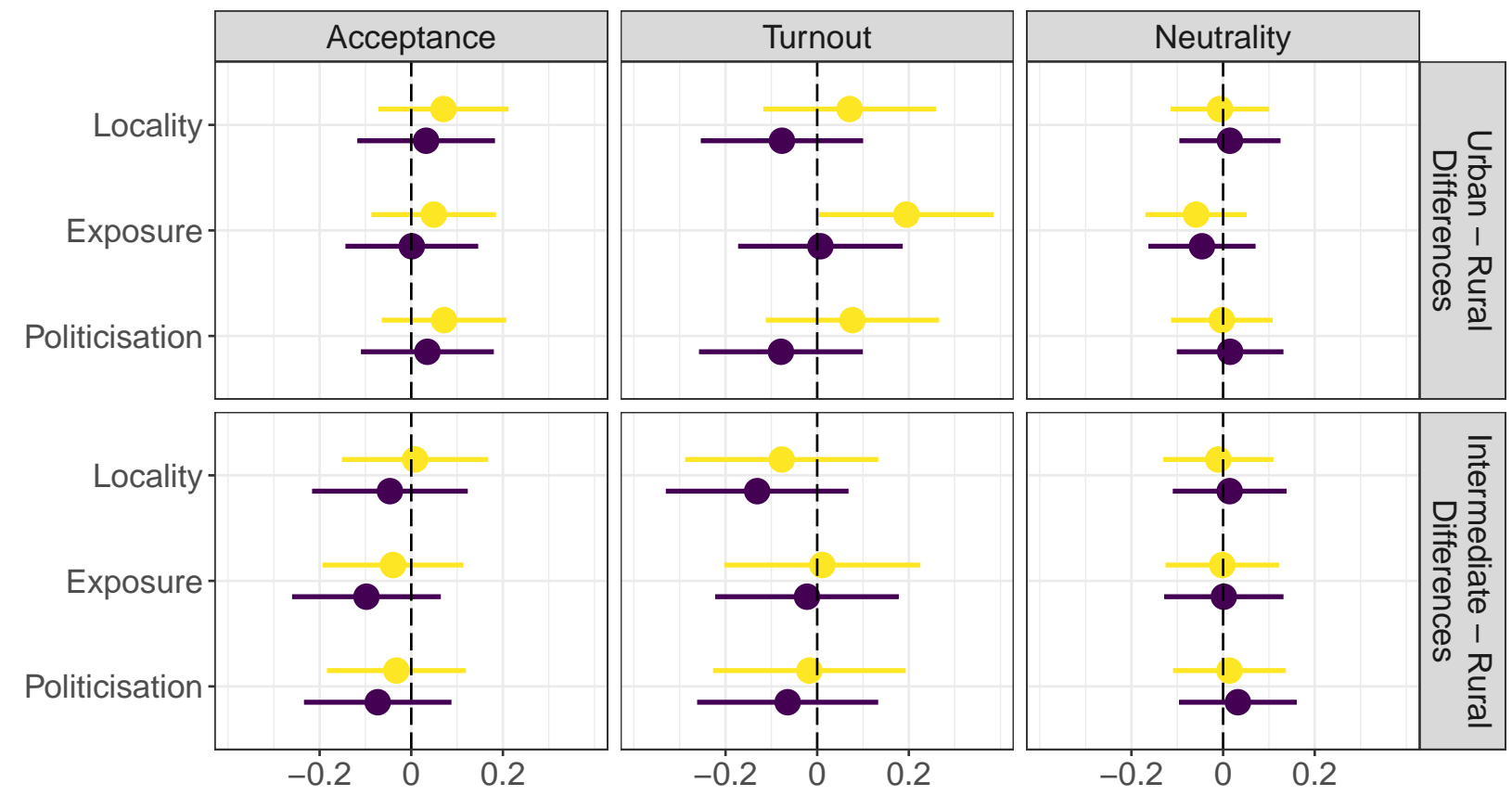

Estimated Difference

Models ... without with ... control variables

Figure 3: Differences in Conditional Marginal Means. Note: The factors are coded as own $=1$ vs. different $=0$ canton (Locality), photographs with $=1 \mathrm{vs}$. without $=0$ a wind turbine (Exposure), and politicised $=1$ vs. unpoliticised $=0$ arguments (Politicisation). 
whether and how parties politicise the issue of wind turbines. This is why we estimated ACIEs (Auspurg and Hinz, 2014; Hainmueller et al., 2014) for parties that support or oppose wind turbines in our vignette, with interactions between Locality and Politicisation as well as between Exposure and Politicisation. We report the results in Table A3 in the Appendix, which shows that these interactions are substantively small and statistically insignificant.

Figure 4 visualises the average marginal effects of Locality and Exposure on vote choice for parties that support (Social Democratic Party of Switzerland) or oppose (Swiss People's Party) wind turbines, depending on whether our treatments informed respondents about their issue positions. It shows that, even when our treatments supplied respondents with party positions on wind turbines $($ Politicisation $=$ Yes $)$, there is no meaningful effect of location or exposure on vote choice for or against these parties. Point estimates are very close to zero, which is within confidence intervals. ${ }^{4}$

\section{Discussion}

These results should be extrapolated beyond the context of our study with caution. External validity is a typical concern in survey experiments (Barabas and Jerit, 2010), and our study is not an exception. Would the results reported above hold if we were to use a different vignette and/or conduct our study in another country? In this section, we discuss the potential limitations of our study over this question.

The choice of parties for the politicisation factor is a good example. In choosing parties to be included in the vignette, we had three criteria in mind - that they should (1) be on the opposite sides of the centre of the left-right dimension, (2) have a clear and opposing position towards building more wind turbines in Switzerland, and that (3) be mainstream, large, and somewhat comparable in size. While the combination of the Social Democratic Party of Switzerland and the Swiss People's Party fits these criteria very well, our vignette excluded the other parties in the election. Particularly, referring to a Green party instead could have made a difference in terms of effects on vote choice, due to their ownership of environmental issues. Experimental designs that

\footnotetext{
${ }^{4}$ One concern is that our design is likely to be underpowered to detect meaningful interaction effects. However, there are two indicators that, even with higher statistical power, our conclusions would not be different. One is that the confidence intervals are narrow about the null value, especially considering that the outcome variables are on a five-point scale. Second, the results from the models with Neutrality as an outcome measure of vote choice, which does not require estimating interactions, return the same null result as well.
} 

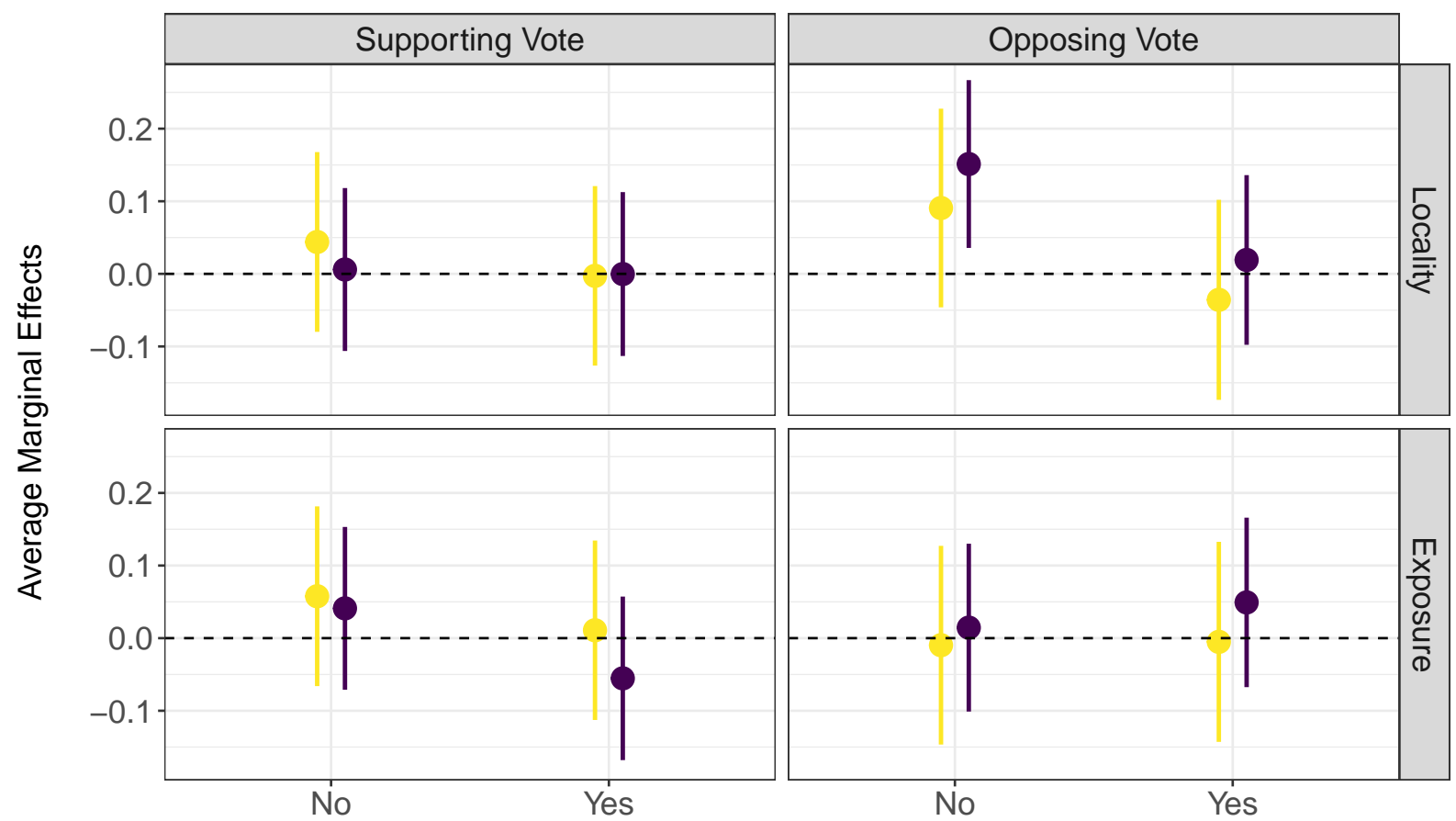

Politicisation

Models ... without with ... control variables

Figure 4: Average marginal effects, following regression models with interactions between factors (ACIEs). Note: The factors are coded as own $=1 \mathrm{vs}$. different $=0$ canton (Locality), photographs with $=1$ vs. without $=0$ a wind turbine (Exposure), and politicised $=1$ vs. unpoliticised $=0$ arguments (Politicisation). 
accommodate references to multiple parties, or ones that can introduce politicisation without any such explicit reference, could offer solutions to this limitation of our study.

A similar caveat applies to the photograph used in the experiment. We chose a photograph that displays a (1) conventional, (2) single turbine in a (3) natural landscape with (4) high aesthetic appeal. Our choices, we believe, reflect what many would imagine a wind turbine to look like in Switzerland - as they are built 'often in attractive and unspoiled areas' (Hirsh and Sovacool, 2013, p. 724). Yet, the photograph does include potentially moderating - at least four - factors, and we need further studies to understand whether a different choice would change the results. For example, a variation in the number of turbines displayed could be informative. Existing studies suggest that exposure improves attitudes through adjusting people's estimation of how much a proposed turbine would in fact spoil the landscape. However, it could also be that, once the landscape is spoiled with one or more turbines, exposure adjusts the estimation of the aesthetic appeal of the landscape instead. Indeed, the survey respondents who received the photograph with the turbine might have thought that the new turbines would be built next to the existing one. Experimental designs that vary the number of turbines displayed could help us understand the mechanisms through which exposure affects public acceptance and electoral outcomes.

The use of cantons as location cues might also have an effect on how well the results here apply to other settings. Here our choice follows from the ideas that (1) the local opposition is more about place identity than distance to turbines (Wolsink, 2006) and (2) there is a strong sense of cantonal identity in Switzerland (Kriesi and Trechsel, 2008, pp. 10-16). Besides, the Swiss cantons are geographically large enough to accommodate the related claims in the vignette that there are (3) proposals to place wind turbines and (4) landscapes similar to the one displayed in each canton. Unlike the other alternatives, such as communes, cantons meet these criteria well. However, cantons might be too large a location to have a significant effect on respondents' attitudes towards wind turbines or their intended electoral behaviour. Experimental designs that use the closest and furthest suitable location to each respondent-irrespective of the corresponding subdivision of these locations - could offer improvements over our design.

Finally, we conducted our study in Switzerland - a country with a number of distinctive features such as consociationalism, cantonal autonomy, and direct democracy (Kriesi and Trechsel, 2008). 
As a result, Swiss voters have multiple veto points, and even if they were sensitive to wind turbine proposals, federal elections may not necessarily be where their sensitivity reveals itself. Among others, the support for or opposition against wind turbines can also be organised at a local (cantonal or communal) level and/or through referenda. Having said that, such multiple electoral arenas are often intertwined in general (Golder, Lago, Blais, Gidengil, and Gschwend, 2017) as formal divisions are ignored by voters (Johns, 2011), members of parliaments (Umit, 2017), and parties (Stecker, 2015) in electoral competition. Specifically, the electoral competition in Switzerland has become less and less distinct over time (Bühlmann, Nicolet, and Selb, 2006). As elsewhere, Swiss parties take increasingly polarising positions in federal elections (Bühlmann et al., 2006), and voters react to these positions predictably in the ballot box (Christin and Schulz, 2006; Nicolet and Sciarini, 2006). In our single-country study, we used two such party positions immediately before a federal election, and further studies in unitary systems would be a test for the external validity of our results related to electoral outcomes.

\section{Conclusion}

Does project locality, turbine exposure, or issue politicisation affect attitudes towards wind turbines or behaviour in elections? Following the conventional wisdom, one would expect to find several causal links within this setting. On the one hand, existing studies repeatedly show that opposition to wind turbines is particularly high among the local residents, but with exposure to turbines, the opposition declines. Similarly, there are also reports that local wind turbines increase turnout and affect vote choice. On the other hand, political parties are increasingly making their views heard on energy policy, including the transition to renewables through wind turbines, suggesting that they expect there are votes to be won and lost over this issue (Lüth and Schaffer, in press).

To test whether these relationships are causal or not, we surveyed over 4,000 respondents, representative of voting-age population in Switzerland, shortly before the 2019 Swiss federal elections. All respondents read a short text about wind turbines with a systematic randomisation with regard to (a) whether they were told that turbines were proposed for their own or another canton, (b) whether

they were shown a landscape photograph with or without a turbine, and (c) whether they were told there was a disagreement over wind turbines between people or political parties. We then estimated 
the effect of each factor on respondents' attitude towards wind turbines and their intended political behaviour in the upcoming election.

The results do not support our expectations or the existing literature. We find that local or politicised wind turbine projects do not make respondents more or less likely to accept wind turbines in Switzerland. Neither do these factors affect - be it on their own, or in combination with one another - voters' electoral behaviour, in terms of turnout and vote choice. The sole exception seems to be the exposure to wind turbines, but only when it comes to public acceptance. Here we find that respondents' support for wind turbine increased as a direct result of seeing the landscape picture with a completed wind turbine, in comparison to seeing the same landscape without one. Then again, there were no meaningful differences between these two groups in terms of electoral behaviour. Likewise, when we compare the sub-groups along the urban-rural divide, we find no notable differences, substantively or statistically. These null findings, nevertheless, can be considered as good news for governments and indeed political parties pushing for more wind turbines in their country. Our results suggest that the electorate may not punish them for their position on wind turbines, even in areas where these turbines will be located. However, our results also suggest that there may be no electoral reward for parties taking the lead in fighting climate change either. 


\section{References}

Álvarez-Farizo, B., and Hanley, N. (2002). Using conjoint analysis to quantify public preferences over the environmental impacts of wind farms. An example from spain. Energy Policy, 30(2), $107-116$.

ARE - Federal Office for Spatial Development. (2017). Konzept windenergie: Basis zur berücksichtigung der bundesinteressen bei der planung von windenergieanlagen. Retrieved from https://www.are.admin.ch/are/de/home/medien-und-publikationen/publikationen/strategieund-planung/konzept-windenergie.html

Auspurg, K., and Hinz, T. (2014). Factorial survey experiments. London: Sage.

Barabas, J., and Jerit, J. (2010). Are survey experiments externally valid? American Political Science Review, $104(2), 226-242$.

Baxter, J., Morzaria, R., and Hirsch, R. (2013). A case-control study of support/opposition to wind turbines: Perceptions of health risk, economic benefits, and community conflict. Energy Policy, 61, 931-943.

Bishop, I. D., and Miller, D. R. (2007). Visual assessment of off-shore wind turbines: The influence of distance, contrast, movement and social variables. Renewable Energy, 32(5), 814-831.

Bolsen, T., Druckman, J. N., and Cook, F. L. (2014). How frames can undermine support for scientific adaptations: Politicization and the status-quo bias. Public Opinion Quarterly, 78(1), $1-26$.

Boudet, H. S. (2019). Public perceptions of and responses to new energy technologies. Nature Energy, 4(6), 446-455.

Boudreau, C., and MacKenzie, S. A. (2014). Informing the electorate? How party cues and policy information affect public opinion about initiatives. American Journal of Political Science, 58(1), $48-62$.

Bues, A., and Gailing, L. (2016). Energy transitions and power: Between governmentality and depoliticization. In L. Gailing and T. Moss (Eds.), Conceptualizing Germany's energy transition (pp. 69-91). London: Palgrave.

Bühlmann, M., Nicolet, S., and Selb, P. (2006). National elections in Switzerland: An introduction. Swiss Political Science Review, 12(4), 1-12. 
Bush, D., and Hoagland, P. (2016). Public opinion and the environmental, economic and aesthetic impacts of offshore wind. Ocean \& Coastal Management, 120, 70-79.

Cashmore, M., Rudolph, D., Larsen, S. V., and Nielsen, H. (2019). International experiences with opposition to wind energy siting decisions: Lessons for environmental and social appraisal. Journal of Environmental Planning and Management, 62(7), 1109-1132.

Christin, T., and Schulz, T. (2006). Is consensual politicizing being punished in Switzerland? Swiss Political Science Review, 12(4), 101-130.

Dear, M. (1992). Understanding and overcoming the NIMBY syndrome. Journal of the American Planning Association, 58(3), 288-300.

Devine-Wright, P. (2009). Rethinking NIMBYism: The role of place attachment and place identity in explaining place-protective action. Journal of Community \& Applied Social Psychology, 19(6), 426-441.

Fergen, J., and Jacquet, J. B. (2016). Beauty in motion: Expectations, attitudes, and values of wind energy development in the rural US. Energy Research 85 Social Science, 11, 133-141.

Firestone, J., and Kempton, W. (2007). Public opinion about large offshore wind power: Underlying factors. Energy Policy, 35(3), 1584-1598.

Firestone, J., and Kirk, H. (2019). A strong relative preference for wind turbines in the United States among those who live near them. Nature Energy, 4(4), 311.

Gaede, J., and Rowlands, I. H. (2018). Visualizing social acceptance research: A bibliometric review of the social acceptance literature for energy technology and fuels. Energy Research $\mathcal{E}$ Social Science, 40, 142-158.

Gärling, T. (2007). Effectiveness, public acceptance, and political feasibility of coercive measures for reducing car traffic. In T. Gärling and L. Steg (Eds.), Threats from car traffic to the quality of urban life: Problems, causes and solutions (pp. 313-324). Bingley: Emerald.

Gilley, B. (2012). Authoritarian environmentalism and China's response to climate change. Environmental Politics, 21(2), 287-307.

Gipe, P. (1993). The wind industry's experience with aesthetic criticism. Leonardo, 26(3), 243-248.

Golder, S. N., Lago, I., Blais, A., Gidengil, E., and Gschwend, T. (2017). Multi-level electoral politics: Beyond the second-order election model. Oxford University Press.

Groothuis, P. A., Groothuis, J. D., and Whitehead, J. C. (2008). Green vs. Green: Measuring 
the compensation required to site electrical generation windmills in a viewshed. Energy Policy, $36(4), 1545-1550$.

Hainmueller, J., Hopkins, D. J., and Yamamoto, T. (2014). Causal inference in conjoint analysis: Understanding multidimensional choices via stated preference experiments. Political Analysis, 22(1), 1-30.

Hevia-Koch, P., and Ladenburg, J. (2019). Where should wind energy be located? A review of preferences and visualisation approaches for wind turbine locations. Energy Research $E^{3}$ Social Science, 53, 23-33.

Hirsh, R. F., and Sovacool, B. K. (2013). Wind turbines and invisible technology: Unarticulated reasons for local opposition to wind energy. Technology and Culture, 54 (4), 705-734.

Hoen, B., Firestone, J., Rand, J., Elliot, D., Hübner, G., Pohl, J., .. Kaliski, K. (2019). Attitudes of US wind turbine neighbors: Analysis of a nationwide survey. Energy Policy, 134, 110981.

IEA - International Energy Agency. (2019). IEA wind TCP 2017 annual report. Retrieved from https://community.ieawind.org/publications/ar?page $=1$

Jeong, G.-H., and Lowry, W. (2021). The polarisation of energy policy in the US Congress. Journal of Public Policy, 41(1), 17-41.

Johansson, M., and Laike, T. (2007). Intention to respond to local wind turbines: The role of attitudes and visual perception. Wind Energy: An International Journal for Progress and Applications in Wind Power Conversion Technology, 10(5), 435-451.

Johns, R. (2011). Credit where it's due? Valence politics, attributions of responsibility, and multi-level elections. Political Behavior, 33(1), 53-77.

Kane, J. V., and Barabas, J. (2019). No harm in checking: Using factual manipulation checks to assess attentiveness in experiments. American Journal of Political Science, 63(1), 234-249.

Kelly-Reif, K., and Wing, S. (2016). Urban-rural exploitation: An underappreciated dimension of environmental injustice. Journal of Rural Studies, 47, 350-358.

Klick, H., and Smith, E. R. (2010). Public understanding of and support for wind power in the United States. Renewable Energy, 35(7), 1585-1591.

Kriesi, H., and Trechsel, A. H. (2008). The politics of Switzerland: Continuity and change in a consensus democracy. Cambridge: Cambridge Univesity Press.

Kuzemko, C. (2016). Energy depoliticisation in the UK: Destroying political capacity. British 
Journal of Politics and International Relations, 18(1), 107-124.

Ladenburg, J., Termansen, M., and Hasler, B. (2013). Assessing acceptability of two onshore wind power development schemes: A test of viewshed effects and the cumulative effects of wind turbines. Energy, 54, 45-54.

Leeper, T. J., Hobolt, S., and Tilley, J. (2020). Measuring subgroup preferences in conjoint experiments. Political Analysis, 28(2), 207-221.

Lüth, M., and Schaffer, L. M. (in press). The electoral importance and evolution of climate related energy policy: Evidence from Switzerland. Swiss Political Science Review.

Mansfield, C., Van Houtven, G., and Huber, J. (2001). The efficiency of political mechanisms for siting nuisance facilities: Are opponents more likely to participate than supporters? Journal of Real Estate Finance and Economics, 22(2-3), 141-161.

Mulvaney, K. K., Woodson, P., and Prokopy, L. S. (2013). Different shades of green: A case study of support for wind farms in the rural midwest. Environmental Management, 51 (5), 1012-1024.

Nicolet, S., and Sciarini, P. (2006). When do issue opinions matter, and to whom? The determinants of long-term stability and change in party choice in the 2003 Swiss elections. Swiss Political Science Review, 12(4), 159-190.

Pasqualetti, M. J. (2011). Opposing wind energy landscapes: A search for common cause. Annals of the Association of American Geographers, 101 (4), 907-917.

Pasqualetti, M. J., Gipe, P., and Righter, R. W. (2002). Wind power in view: Energy landscapes in a crowded world. San Diego: Academic Press.

Petrova, M. A. (2014). Sustainable communities and wind energy project acceptance in Massachusetts. Minn. JL Sci. E Tech., 15, 529.

Rand, J., and Hoen, B. (2017). Thirty years of North American wind energy acceptance research: What have we learned? Energy Research 65 Social Science, 29, 135-148.

REN21 - Renewable Energy Policy Network for the 21st Century. (2019). Renewables 2019: Global status report. Retrieved from https://www.ren21.net/reports/global-status-report

Schäffer, B., Pieren, R., Hayek, U. W., Biver, N., and Grêt-Regamey, A. (2019). Influence of visibility of wind farms on noise annoyance-a laboratory experiment with audio-visual simulations. Landscape and Urban Planning, 186, 67-78.

SFOE - Swiss Federal Office of Energy. (2019). Wind turbine sites in operation [dashboard]. 
Retrieved September 1, 2019, from https://wind-data.ch/wka/list.php

Sherren, K., Parkins, J. R., Owen, T., and Terashima, M. (2019). Does noticing energy infrastructure influence public support for energy development? Evidence from a national survey in Canada. Energy Research 8 Social Science, 51, 176-186.

Stecker, C. (2015). Parties on the chain of federalism: Position-taking and multi-level party competition in Germany. West European Politics, 38(6), 1305-1326.

Stokes, L. C. (2016). Electoral backlash against climate policy: A natural experiment on retrospective voting and local resistance to public policy. American Journal of Political Science, 60 (4), 958-974.

Umit, R. (2017). Communication without legislation? A cross-national field experiment on members of parliament. Representation, 53(2), 117-134.

Walker, C., Mason, S., and Bednar, D. (2018). Sustainable development and environmental injustice in rural Ontario, Canada: Cases of wind energy and biosolid processing. Journal of Rural and Community Development, 13(2), 110-129.

Walker, C., Stephenson, L., and Baxter, J. (2018). "His main platform is "stop the turbines'": Political discourse, partisanship and local responses to wind energy in Canada. Energy Policy, 123, 670-681.

Wolsink, M. (2006). Invalid theory impedes our understanding: A critique on the persistence of the language of NIMBY. Transactions of the Institute of British Geographers, 31(1), 85-91.

Wolsink, M. (2007). Wind power implementation: The nature of public attitudes: Equity and fairness instead of 'backyard motives.' Renewable and Sustainable Energy Reviews, 11(6), 1188-1207. 


\section{Appendix to}

\section{'Wind Turbines, Public Acceptance, and Electoral Outcomes'}

\section{Descriptive Statistics}

Table A1 provides statistics describing the sample in our survey, with the variables used for analyses in the main text. For more information on these variables, all measured with an online survey, see also the questionnaire below.

Table A1: Descriptive statistics

\begin{tabular}{lcccccc}
\hline \hline Statistic & $\mathrm{N}$ & Mean & Median & St. Dev. & Min & Max \\
\hline Acceptance* & 3,910 & 3.6 & 4.0 & 1.0 & 1.0 & 5.0 \\
Turnout* & 3,531 & 3.9 & 4.0 & 1.3 & 1.0 & 5.0 \\
Neutrality* & 3,608 & 0.6 & 0.0 & 0.8 & 0.0 & 2.0 \\
Supporting Vote* & 3,289 & 2.4 & 2.0 & 1.3 & 1.0 & 5.0 \\
Opposing Vote* & 3,323 & 2.3 & 2.0 & 1.4 & 1.0 & 5.0 \\
Age & 4,077 & 46.4 & 46.0 & 15.2 & 18.0 & 111.0 \\
Female & 4,079 & 0.5 & 1.0 & 0.5 & 0.0 & 1.0 \\
Education & 4,059 & 6.1 & 5.0 & 2.0 & 1.0 & 10.0 \\
Income & 3,323 & 4.6 & 4.0 & 2.5 & 1.0 & 10.0 \\
Years in Canton & 4,083 & 29.3 & 28.0 & 20.0 & 0.0 & 111.0 \\
Climate Worries & 4,000 & 3.1 & 3.0 & 0.8 & 1.0 & 4.0 \\
Political Interest & 4,025 & 2.7 & 3.0 & 0.9 & 1.0 & 4.0 \\
Left-Right & 4,040 & 4.4 & 4.0 & 2.1 & 0.0 & 9.0 \\
\hline
\end{tabular}

Note: ${ }^{*}$ indicates dependent variables.

\section{Population - Sample Comparisons}

We aimed at a sample that is representative of the Swiss voting-age population in terms of age, gender, and region. At the same time, we over-sampled respondents from outside urban areas for the reasons of precision in sub-group estimates. Indeed, research shows that unbiased sub-group analysis require larger and equally-sized groups (Brookes et al., 2004; Burke, Sussman, Kent, and 
Hayward, 2015).

In this section, we visualise summary statistics about our sample, in comparison with the Swiss voting-age population. The data for the latter come from the population statistics in 2018, as published on the Swiss Federal Statistical Office website-www.bfs.admin.ch. A1 shows that share of respondents from each of 26 Swiss cantons was close to the share of population in these cantons. Zurich is perhaps the only exception, which is relatively under-sampled in the survey. This could have emerged due to our strategy to under-sample urban populations.

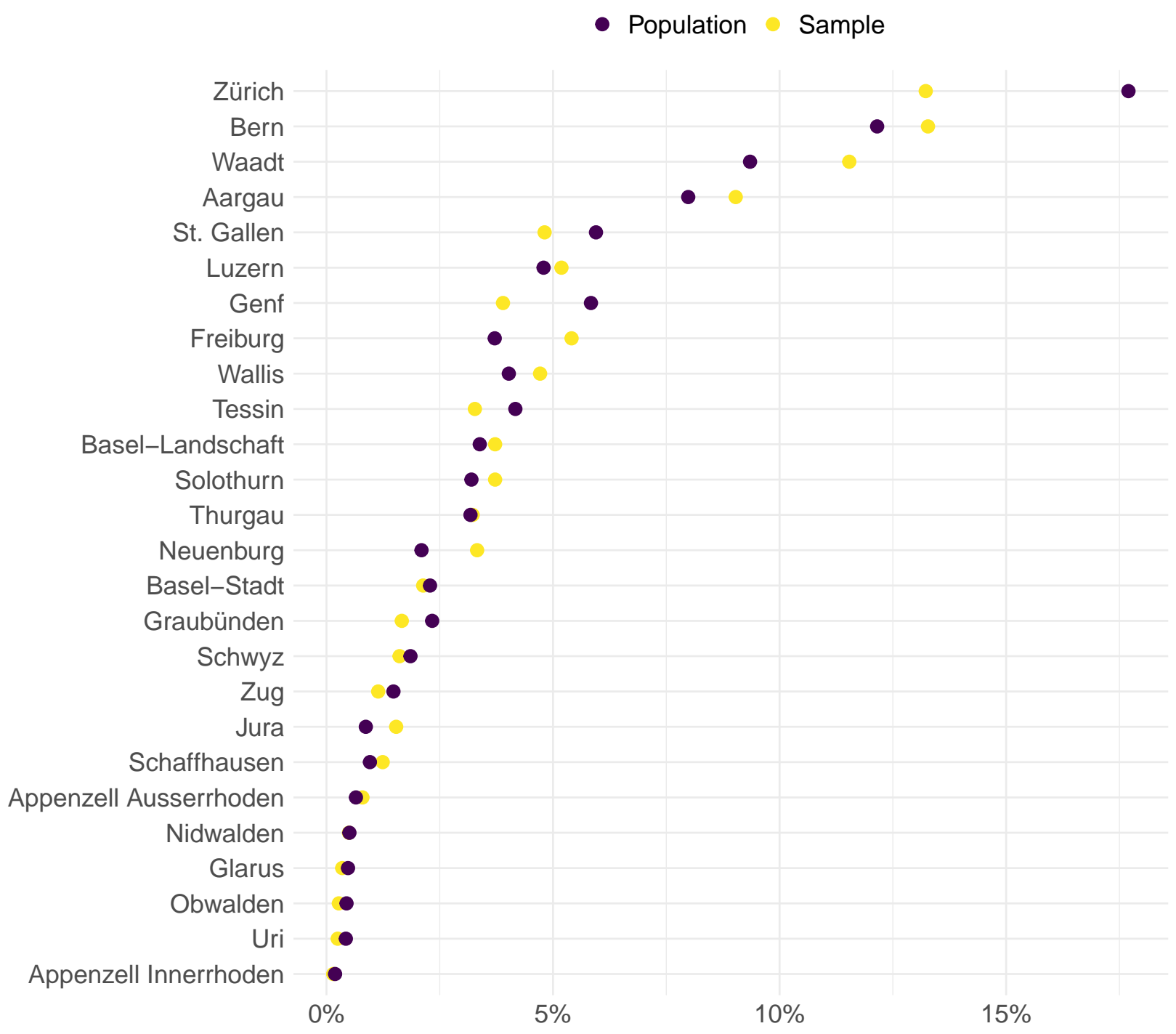

Figure A1: Population and survey respondents, by cantons.

Indeed, Figure A2 shows that our strategy to increase the balance between urban, intermediate, 
and rural areas had an effect on the sample; we oversampled respondents from intermediate and rural areas at the expense of respondents from urban areas.

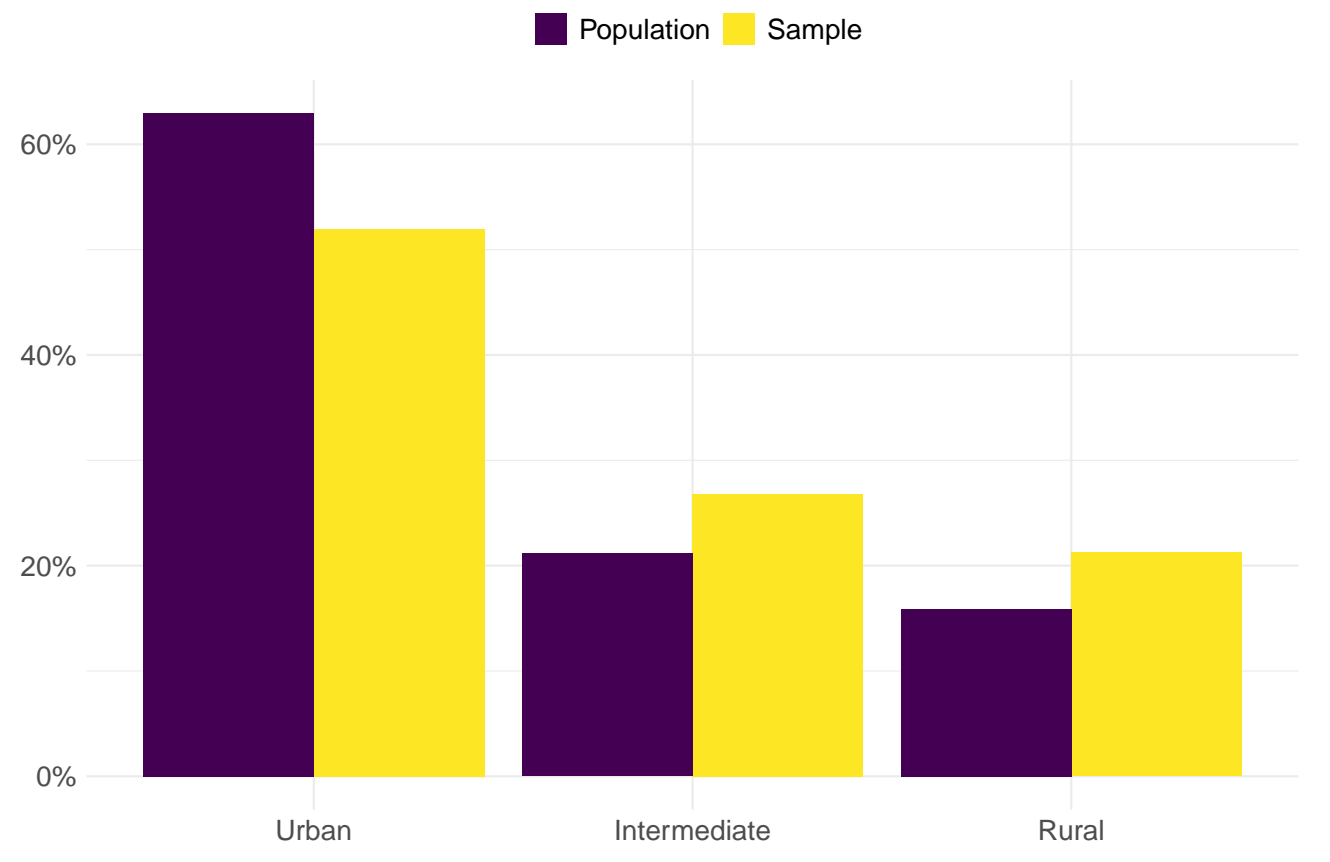

Figure A2: Population and survey respondents, by urban-rural classification.

Finally, Figure A3 plots the distributions of the Swiss population and our survey respondents, by age and gender. It shows that there is a considerably match between the two, although our sample was slightly younger and it had a higher share of females than in the population. 


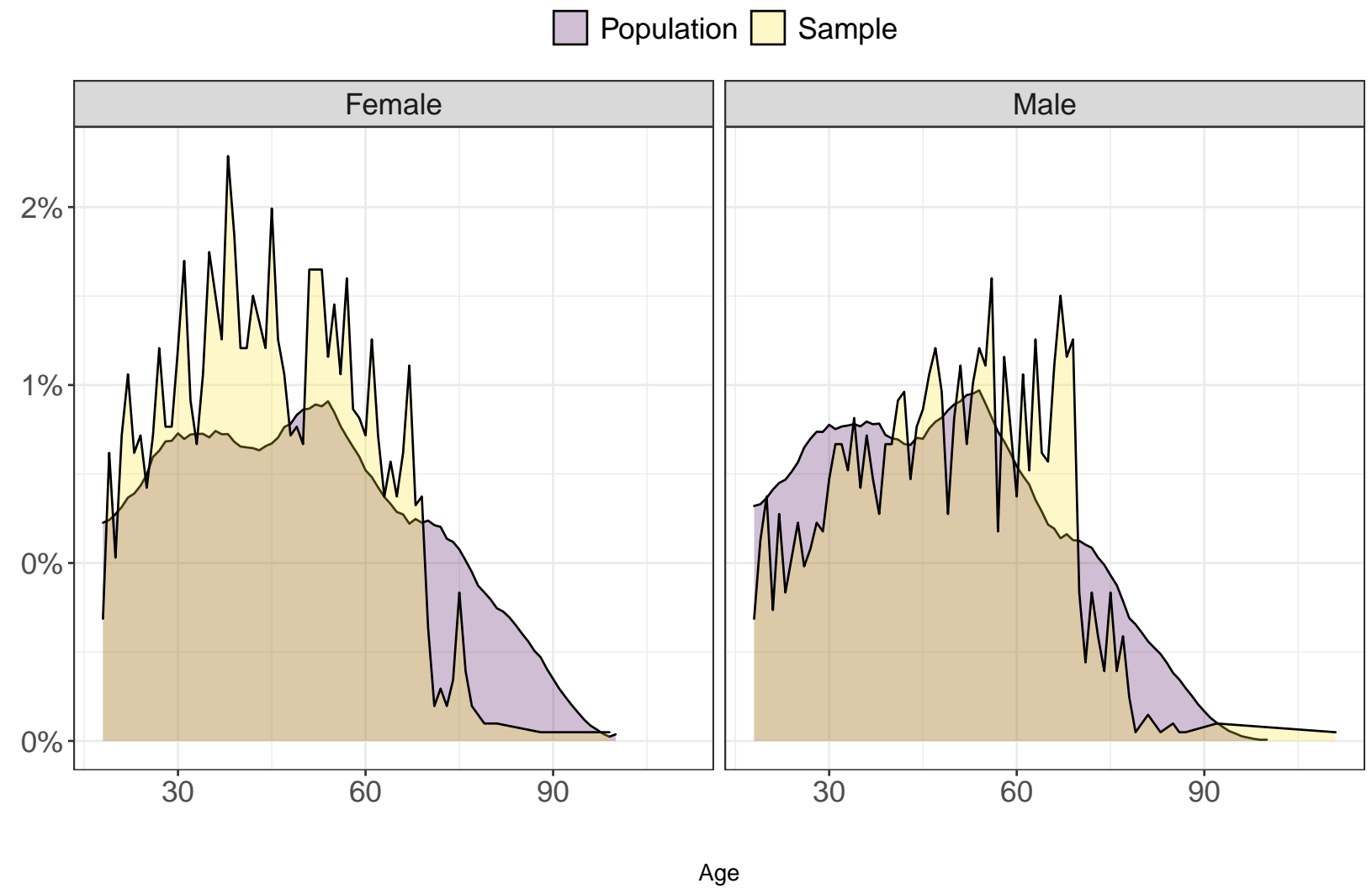

Figure A3: Population and survey respondents, by gender and age. 


\section{Manipulation Check}

In this section, we visualise the manipulation check failures, by question subject and survey language. Figure A4 shows that respondents were more likely to fail if they received the manipulation check on politicisation. However, the results are relatively similar in terms of language.

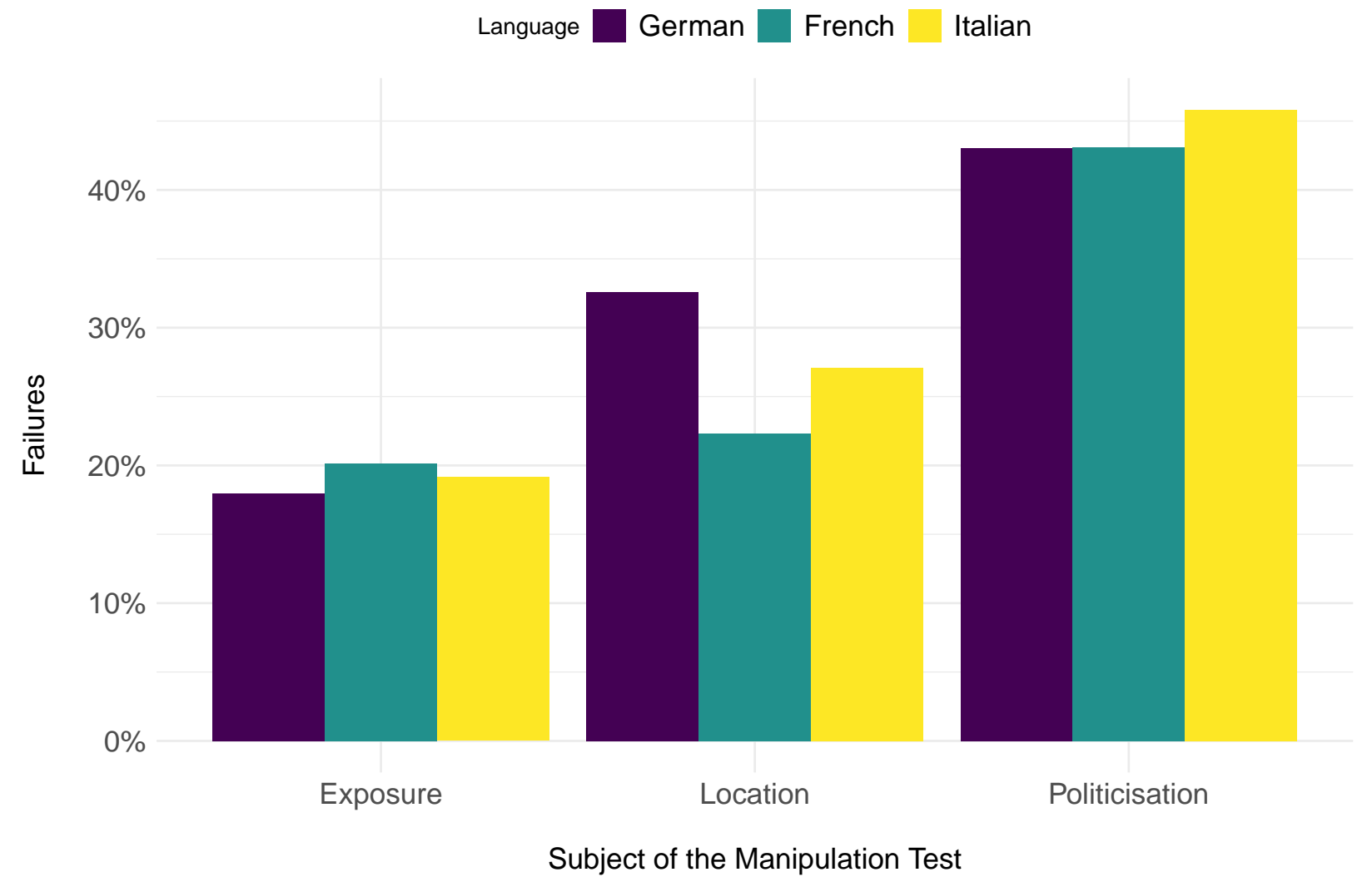

Figure A4: Manipulation check failures, by question subject and survey language.

\section{Vignette Screenshot}

Figure A5 shows a screenshot of the survey, showing how the experimental component appeared on computer screen for respondents. 
To increase the amount of electricity generated from renewable sources of energy, there are proposals to place wind turbines in the canton of Lucerne, in landscapes similar to the one pictured below.

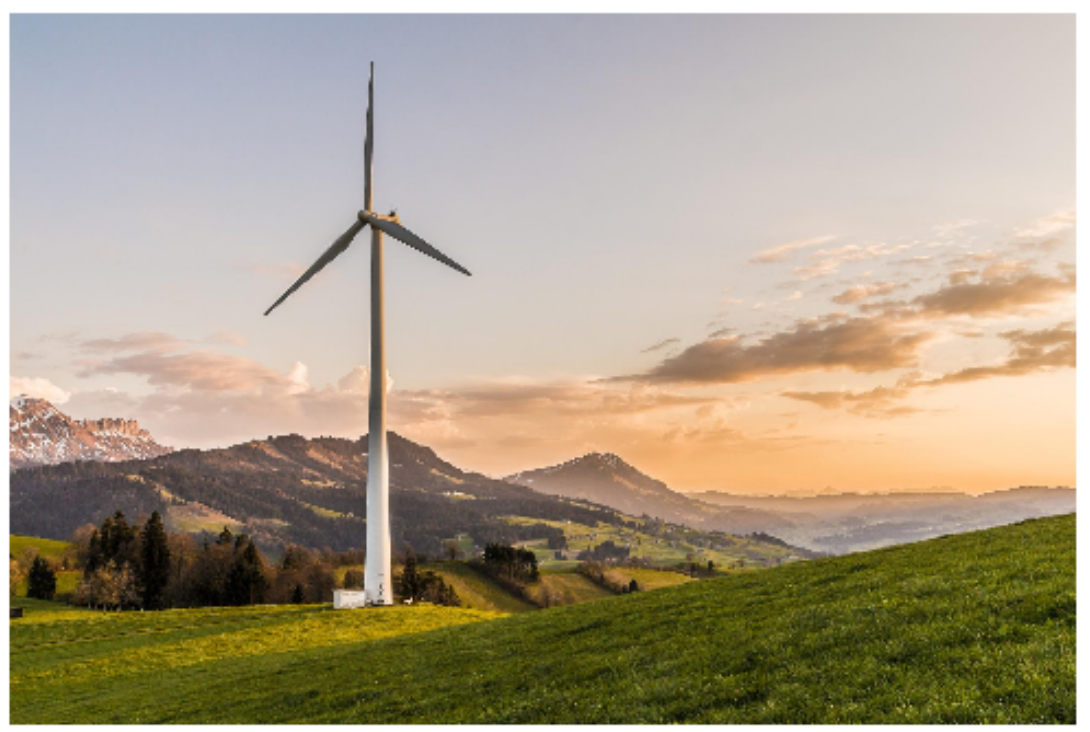

There has been a mixed reaction to these proposals. Some people support these proposals while other people oppose them.

How about you? Do you support or oppose these wind turbine proposals?

Strongly support

Support

Neither support nor oppose

Oppose

Strongly oppose

Don't know

Figure A5: A screenshot from the survey. 


\section{Complete Tables}

In this section, we provide the complete results in table format for two figures in the main text; see Table A2 for the average marginal component effects (Figure 2), and Table A3 for average component interaction effects (Figure 4).

Table A2: Complete OLS results for Figure 2

\begin{tabular}{|c|c|c|c|c|c|c|}
\hline & \multicolumn{2}{|c|}{ Acceptance } & \multicolumn{2}{|c|}{ Turnout } & \multicolumn{2}{|c|}{ Neutrality } \\
\hline & $(1)$ & $(2)$ & $(3)$ & $(4)$ & $(5)$ & $(6)$ \\
\hline Locality & $\begin{array}{l}-0.04 \\
(0.03)\end{array}$ & $\begin{array}{l}-0.03 \\
(0.03)\end{array}$ & $\begin{array}{c}0.07 \\
(0.04)\end{array}$ & $\begin{array}{c}0.08 \\
(0.04)\end{array}$ & $\begin{array}{l}-0.02 \\
(0.03)\end{array}$ & $\begin{array}{l}-0.03 \\
(0.03)\end{array}$ \\
\hline Exposure & $\begin{array}{c}0.13^{* * *} \\
(0.03)\end{array}$ & $\begin{array}{c}0.13^{* * *} \\
(0.03)\end{array}$ & $\begin{array}{c}0.03 \\
(0.04)\end{array}$ & $\begin{array}{c}0.04 \\
(0.04)\end{array}$ & $\begin{array}{l}0.05^{*} \\
(0.03)\end{array}$ & $\begin{array}{l}0.07^{* *} \\
(0.03)\end{array}$ \\
\hline Politicisation & $\begin{array}{c}0.01 \\
(0.03)\end{array}$ & $\begin{array}{c}0.02 \\
(0.03)\end{array}$ & $\begin{array}{c}0.01 \\
(0.04)\end{array}$ & $\begin{array}{c}0.01 \\
(0.04)\end{array}$ & $\begin{array}{c}0.04 \\
(0.03)\end{array}$ & $\begin{array}{c}0.01 \\
(0.03)\end{array}$ \\
\hline Age & & $\begin{array}{c}-0.01^{* * *} \\
(0.001)\end{array}$ & & $\begin{array}{l}0.01^{* * *} \\
(0.002)\end{array}$ & & $\begin{array}{c}-0.003^{* *} \\
(0.001)\end{array}$ \\
\hline Female & & $\begin{array}{l}-0.06 \\
(0.04)\end{array}$ & & $\begin{array}{c}0.04 \\
(0.04)\end{array}$ & & $\begin{array}{c}0.06^{*} \\
(0.03)\end{array}$ \\
\hline Education & & $\begin{array}{l}-0.02 \\
(0.01)\end{array}$ & & $\begin{array}{c}0.06^{* * *} \\
(0.01)\end{array}$ & & $\begin{array}{c}-0.02^{*} \\
(0.01)\end{array}$ \\
\hline Income & & $\begin{array}{c}0.01 \\
(0.01)\end{array}$ & & $\begin{array}{c}0.05^{* * *} \\
(0.01)\end{array}$ & & $\begin{array}{l}-0.01 \\
(0.01)\end{array}$ \\
\hline Urban-Rural & & $\begin{array}{l}-0.02 \\
(0.02)\end{array}$ & & $\begin{array}{c}0.01 \\
(0.03)\end{array}$ & & $\begin{array}{l}0.001 \\
(0.02)\end{array}$ \\
\hline Years in Canton & & $\begin{array}{l}-0.001 \\
(0.001)\end{array}$ & & $\begin{array}{c}0.003^{*} \\
(0.001)\end{array}$ & & $\begin{array}{l}0.0002 \\
(0.001)\end{array}$ \\
\hline Climate Worries & & $\begin{array}{c}0.26^{* * *} \\
(0.02)\end{array}$ & & $\begin{array}{c}0.06^{*} \\
(0.03)\end{array}$ & & $\begin{array}{c}0.04^{*} \\
(0.02)\end{array}$ \\
\hline Political Interest & & $\begin{array}{c}0.01 \\
(0.02)\end{array}$ & & $\begin{array}{c}0.69^{* * *} \\
(0.03)\end{array}$ & & $\begin{array}{c}-0.15^{* * *} \\
(0.02)\end{array}$ \\
\hline Left-Right & & $\begin{array}{c}-0.05^{* * *} \\
(0.01)\end{array}$ & & $\begin{array}{l}-0.01 \\
(0.01)\end{array}$ & & $\begin{array}{c}-0.002 \\
(0.01)\end{array}$ \\
\hline Constant & $\begin{array}{c}3.60^{* * *} \\
(0.03) \\
\end{array}$ & $\begin{array}{c}3.39^{* * *} \\
(0.14) \\
\end{array}$ & $\begin{array}{c}3.87^{* * *} \\
(0.05) \\
\end{array}$ & $\begin{array}{c}0.70^{* * *} \\
(0.17) \\
\end{array}$ & $\begin{array}{c}0.56^{* * *} \\
(0.03) \\
\end{array}$ & $\begin{array}{c}1.10^{* * *} \\
(0.11)\end{array}$ \\
\hline Observations & 3,910 & 3,221 & 3,531 & 2,924 & 3,608 & 2,973 \\
\hline $\mathrm{R}^{2}$ & 0.005 & 0.07 & 0.001 & 0.29 & 0.002 & 0.06 \\
\hline
\end{tabular}

Note: $\quad{ }^{*} \mathrm{p}<0.05 ;{ }^{* *} \mathrm{p}<0.01 ;{ }^{* * *} \mathrm{p}<0.001$ 
Table A3: Interaction models for Figure 3

\begin{tabular}{|c|c|c|c|c|c|c|c|c|}
\hline & \multicolumn{4}{|c|}{ Supporting Vote } & \multicolumn{4}{|c|}{ Opposing Vote } \\
\hline & $(1)$ & $(2)$ & $(3)$ & $(4)$ & $(5)$ & $(6)$ & $(7)$ & $(8)$ \\
\hline Locality (L) & $\begin{array}{c}0.04 \\
(0.06)\end{array}$ & $\begin{array}{c}0.01 \\
(0.06)\end{array}$ & $\begin{array}{c}0.02 \\
(0.04)\end{array}$ & $\begin{array}{l}0.003 \\
(0.04)\end{array}$ & $\begin{array}{c}0.09 \\
(0.07)\end{array}$ & $\begin{array}{l}0.15^{*} \\
(0.06)\end{array}$ & $\begin{array}{c}0.03 \\
(0.05)\end{array}$ & $\begin{array}{l}0.09^{*} \\
(0.04)\end{array}$ \\
\hline Exposure (E) & $\begin{array}{c}0.03 \\
(0.04)\end{array}$ & $\begin{array}{l}-0.01 \\
(0.04)\end{array}$ & $\begin{array}{c}0.06 \\
(0.06)\end{array}$ & $\begin{array}{c}0.04 \\
(0.06)\end{array}$ & $\begin{array}{l}-0.01 \\
(0.05)\end{array}$ & $\begin{array}{c}0.03 \\
(0.04)\end{array}$ & $\begin{array}{l}-0.01 \\
(0.07)\end{array}$ & $\begin{array}{c}0.01 \\
(0.06)\end{array}$ \\
\hline Politicisation (P) & $\begin{array}{c}0.03 \\
(0.06)\end{array}$ & $\begin{array}{c}0.01 \\
(0.06)\end{array}$ & $\begin{array}{c}0.03 \\
(0.06)\end{array}$ & $\begin{array}{c}0.05 \\
(0.06)\end{array}$ & $\begin{array}{c}0.09 \\
(0.07)\end{array}$ & $\begin{array}{c}0.10 \\
(0.06)\end{array}$ & $\begin{array}{c}0.02 \\
(0.07)\end{array}$ & $\begin{array}{c}0.02 \\
(0.06)\end{array}$ \\
\hline $\mathrm{L} x \mathrm{P}$ & $\begin{array}{l}-0.05 \\
(0.09)\end{array}$ & $\begin{array}{l}-0.01 \\
(0.08)\end{array}$ & & & $\begin{array}{l}-0.13 \\
(0.10)\end{array}$ & $\begin{array}{l}-0.13 \\
(0.08)\end{array}$ & & \\
\hline $\mathrm{E} x \mathrm{P}$ & & & $\begin{array}{l}-0.05 \\
(0.09)\end{array}$ & $\begin{array}{l}-0.10 \\
(0.08)\end{array}$ & & & $\begin{array}{l}0.005 \\
(0.10)\end{array}$ & $\begin{array}{c}0.03 \\
(0.08)\end{array}$ \\
\hline Age & & $\begin{array}{c}-0.01^{* * *} \\
(0.002)\end{array}$ & & $\begin{array}{c}-0.01^{* * *} \\
(0.002)\end{array}$ & & $\begin{array}{l}-0.002 \\
(0.002)\end{array}$ & & $\begin{array}{l}-0.002 \\
(0.002)\end{array}$ \\
\hline Female & & $\begin{array}{c}0.16^{* * *} \\
(0.04)\end{array}$ & & $\begin{array}{c}0.16^{* * *} \\
(0.04)\end{array}$ & & $\begin{array}{c}0.09 \\
(0.04)\end{array}$ & & $\begin{array}{c}0.09 \\
(0.04)\end{array}$ \\
\hline Education & & $\begin{array}{c}-0.002 \\
(0.01)\end{array}$ & & $\begin{array}{c}-0.002 \\
(0.01)\end{array}$ & & $\begin{array}{c}-0.06^{* * *} \\
(0.01)\end{array}$ & & $\begin{array}{c}-0.06^{* * *} \\
(0.01)\end{array}$ \\
\hline Income & & $\begin{array}{c}-0.02^{*} \\
(0.01)\end{array}$ & & $\begin{array}{c}-0.02^{*} \\
(0.01)\end{array}$ & & $\begin{array}{c}-0.03^{* *} \\
(0.01)\end{array}$ & & $\begin{array}{c}-0.03^{* *} \\
(0.01)\end{array}$ \\
\hline Urban-Rural & & $\begin{array}{c}-0.08^{* *} \\
(0.03)\end{array}$ & & $\begin{array}{c}-0.08^{* *} \\
(0.03)\end{array}$ & & $\begin{array}{l}0.07^{*} \\
(0.03)\end{array}$ & & $\begin{array}{l}0.07^{*} \\
(0.03)\end{array}$ \\
\hline Years in Canton & & $\begin{array}{c}0.001 \\
(0.001)\end{array}$ & & $\begin{array}{c}0.001 \\
(0.001)\end{array}$ & & $\begin{array}{l}-0.002 \\
(0.001)\end{array}$ & & $\begin{array}{c}-0.002 \\
(0.001)\end{array}$ \\
\hline Climate Worries & & $\begin{array}{c}0.17^{* * *} \\
(0.03)\end{array}$ & & $\begin{array}{c}0.17^{* * *} \\
(0.03)\end{array}$ & & $\begin{array}{c}-0.16^{* * *} \\
(0.03)\end{array}$ & & $\begin{array}{c}-0.16^{* * *} \\
(0.03)\end{array}$ \\
\hline Political Interest & & $\begin{array}{c}0.19^{* * *} \\
(0.03)\end{array}$ & & $\begin{array}{c}0.19^{* * *} \\
(0.03)\end{array}$ & & $\begin{array}{c}0.17^{* * *} \\
(0.03)\end{array}$ & & $\begin{array}{c}0.18^{* * *} \\
(0.03)\end{array}$ \\
\hline Left-Right & & $\begin{array}{c}-0.29^{* * *} \\
(0.01)\end{array}$ & & $\begin{array}{c}-0.29^{* * *} \\
(0.01)\end{array}$ & & $\begin{array}{c}0.38^{* * *} \\
(0.01)\end{array}$ & & $\begin{array}{c}0.38^{* * *} \\
(0.01)\end{array}$ \\
\hline Constant & $\begin{array}{c}2.36^{* * *} \\
(0.05) \\
\end{array}$ & $\begin{array}{c}3.04^{* * *} \\
(0.17)\end{array}$ & $\begin{array}{c}2.36^{* * *} \\
(0.05) \\
\end{array}$ & $\begin{array}{c}3.02^{* * *} \\
(0.17)\end{array}$ & $\begin{array}{c}2.28^{* * *} \\
(0.06) \\
\end{array}$ & $\begin{array}{c}1.06^{* * *} \\
(0.17)\end{array}$ & $\begin{array}{c}2.31^{* * *} \\
(0.06)\end{array}$ & $\begin{array}{c}1.11^{* * *} \\
(0.17) \\
\end{array}$ \\
\hline Observations & 3,289 & 2,772 & 3,289 & 2,772 & 3,323 & 2,796 & 3,323 & 2,796 \\
\hline $\mathrm{R}^{2}$ & 0.0003 & 0.32 & 0.0003 & 0.32 & 0.001 & 0.40 & 0.0002 & 0.40 \\
\hline
\end{tabular}

Note: $\quad{ }^{*} \mathrm{p}<0.05 ;{ }^{* *} \mathrm{p}<0.01 ;{ }^{* * *} \mathrm{p}<0.001$ 


\section{Exploratory Analyses}

This section provides results from a number of exploratory analyses, which are not pre-registered.

Except for the robustness check with alternative modelling specifications, these exploratory analyses have been added during the peer review process.

\section{Weighted descriptive statistics}

The statistics in Table A4 are weighted with post-stratification weights to correct for over-sampling respondents from outside urban areas.

Table A4: Survey-weighted descriptive statistics

\begin{tabular}{lcccccc}
\hline \hline Statistic & $\mathrm{N}$ & Mean & Median & St. Dev. & Min & Max \\
\hline Acceptance* & 3,910 & 3.7 & 4.0 & 1.0 & 1.0 & 5.0 \\
Turnout* & 3,531 & 3.9 & 4.0 & 1.3 & 1.0 & 5.0 \\
Neutrality* & 3,608 & 0.6 & 0.0 & 0.8 & 0.0 & 2.0 \\
Supporting Vote* & 3,289 & 2.4 & 2.0 & 1.3 & 1.0 & 5.0 \\
Opposing Vote* & 3,323 & 2.3 & 2.0 & 1.4 & 1.0 & 5.0 \\
Age & 4,030 & 46.5 & 46.0 & 15.2 & 18.0 & 111.0 \\
Female & 4,030 & 0.5 & 1.0 & 0.5 & 0.0 & 1.0 \\
Education & 4,018 & 6.1 & 5.0 & 2.0 & 1.0 & 10.0 \\
Income & 3,323 & 4.7 & 4.0 & 2.6 & 1.0 & 10.0 \\
Years in Canton & 4,030 & 29.4 & 28.0 & 20.1 & 0.0 & 111.0 \\
Climate Worries & 3,981 & 3.1 & 3.0 & 0.8 & 1.0 & 4.0 \\
Political Interest & 4,005 & 2.7 & 3.0 & 0.9 & 1.0 & 4.0 \\
Left-Right & 4,030 & 4.3 & 4.0 & 2.1 & 0.0 & 9.0 \\
\hline
\end{tabular}

Note: $*$ indicates dependent variables. 


\section{Weighted regression models}

The statistics in Table A5 are weighted with post-stratification weights to correct for over-sampling respondents from outside urban areas.

Table A5: Main results — with survey-weighted data

\begin{tabular}{|c|c|c|c|c|c|c|}
\hline & \multicolumn{2}{|c|}{ Acceptance } & \multicolumn{2}{|c|}{ Turnout } & \multicolumn{2}{|c|}{ Neutrality } \\
\hline & (1) & $(2)$ & $(3)$ & $(4)$ & $(5)$ & $(6)$ \\
\hline Locality & $\begin{array}{l}-0.04 \\
(0.03)\end{array}$ & $\begin{array}{c}-0.03 \\
(0.03)\end{array}$ & $\begin{array}{c}0.06 \\
(0.05)\end{array}$ & $\begin{array}{c}0.07 \\
(0.04)\end{array}$ & $\begin{array}{l}-0.02 \\
(0.03)\end{array}$ & $\begin{array}{l}-0.03 \\
(0.03)\end{array}$ \\
\hline Exposure & $\begin{array}{c}0.13^{* * *} \\
(0.03)\end{array}$ & $\begin{array}{c}0.13^{* * *} \\
(0.03)\end{array}$ & $\begin{array}{c}0.03 \\
(0.05)\end{array}$ & $\begin{array}{c}0.05 \\
(0.04)\end{array}$ & $\begin{array}{c}0.04 \\
(0.03)\end{array}$ & $\begin{array}{l}0.06^{*} \\
(0.03)\end{array}$ \\
\hline Politicisation & $\begin{array}{c}0.01 \\
(0.03)\end{array}$ & $\begin{array}{c}0.02 \\
(0.03)\end{array}$ & $\begin{array}{l}-0.01 \\
(0.05)\end{array}$ & $\begin{array}{c}-0.0001 \\
(0.04)\end{array}$ & $\begin{array}{c}0.04 \\
(0.03)\end{array}$ & $\begin{array}{c}0.01 \\
(0.03)\end{array}$ \\
\hline Age & & $\begin{array}{c}-0.01^{* * *} \\
(0.001)\end{array}$ & & $\begin{array}{l}0.01^{* * *} \\
(0.002)\end{array}$ & & $\begin{array}{c}-0.003^{* *} \\
(0.001)\end{array}$ \\
\hline Female & & $\begin{array}{c}-0.07^{*} \\
(0.04)\end{array}$ & & $\begin{array}{c}0.04 \\
(0.05)\end{array}$ & & $\begin{array}{c}0.06^{*} \\
(0.03)\end{array}$ \\
\hline Education & & $\begin{array}{l}-0.02 \\
(0.01)\end{array}$ & & $\begin{array}{c}0.06^{* * *} \\
(0.01)\end{array}$ & & $\begin{array}{l}-0.01 \\
(0.01)\end{array}$ \\
\hline Income & & $\begin{array}{c}0.01 \\
(0.01)\end{array}$ & & $\begin{array}{c}0.05^{* * *} \\
(0.01)\end{array}$ & & $\begin{array}{l}-0.01 \\
(0.01)\end{array}$ \\
\hline Urban-Rural & & $\begin{array}{l}-0.02 \\
(0.02)\end{array}$ & & $\begin{array}{l}0.001 \\
(0.03)\end{array}$ & & $\begin{array}{c}0.001 \\
(0.02)\end{array}$ \\
\hline Years in Canton & & $\begin{array}{l}-0.001 \\
(0.001)\end{array}$ & & $\begin{array}{c}0.002 \\
(0.001)\end{array}$ & & $\begin{array}{c}-0.0000 \\
(0.001)\end{array}$ \\
\hline Climate Worries & & $\begin{array}{c}0.26^{* * *} \\
(0.03)\end{array}$ & & $\begin{array}{c}0.05 \\
(0.03)\end{array}$ & & $\begin{array}{c}0.03 \\
(0.02)\end{array}$ \\
\hline Political Interest & & $\begin{array}{c}0.01 \\
(0.02)\end{array}$ & & $\begin{array}{c}0.68^{* * *} \\
(0.03)\end{array}$ & & $\begin{array}{c}-0.16^{* * *} \\
(0.02)\end{array}$ \\
\hline Left-Right & & $\begin{array}{c}-0.05^{* * *} \\
(0.01)\end{array}$ & & $\begin{array}{l}-0.01 \\
(0.01)\end{array}$ & & $\begin{array}{c}-0.0002 \\
(0.01)\end{array}$ \\
\hline Constant & $\begin{array}{c}3.60^{* * *} \\
(0.03) \\
\end{array}$ & $\begin{array}{c}3.37^{* * *} \\
(0.14) \\
\end{array}$ & $\begin{array}{c}3.90^{* * *} \\
(0.05) \\
\end{array}$ & $\begin{array}{c}0.79^{* * *} \\
(0.17) \\
\end{array}$ & $\begin{array}{c}0.56^{* * *} \\
(0.03) \\
\end{array}$ & $\begin{array}{c}1.10^{* * *} \\
(0.11)\end{array}$ \\
\hline Observations & 3,910 & 3,221 & 3,531 & 2,924 & 3,608 & 2,973 \\
\hline Log Likelihood & $-5,611.05$ & $-4,467.99$ & $-6,050.08$ & $-4,518.31$ & $-4,173.34$ & $-3,249.72$ \\
\hline Akaike Inf. Crit. & $11,230.09$ & $8,961.99$ & $12,108.16$ & $9,062.62$ & $8,354.69$ & $6,525.44$ \\
\hline
\end{tabular}




\section{Alternative modelling specifications}

To facilitate interpretation, we reported results from OLS models in the main text. As a robustness check, Table A6 re-runs the models with ordered logistic (for Acceptance and Turnout as dependent variables) or Poisson (for Neutrality, which - unlike the previous two dependent variables - consists of count data) regressions. As mentioned in the main text, our conclusions remain the same.

Table A6: Alternative specifications for Figure 2

\begin{tabular}{|c|c|c|c|c|c|c|}
\hline & \multicolumn{2}{|c|}{$\begin{array}{c}\text { (Ordered Logit) } \\
\text { Acceptance }\end{array}$} & \multicolumn{2}{|c|}{$\begin{array}{c}\text { (Ordered Logit) } \\
\text { Turnout }\end{array}$} & \multicolumn{2}{|c|}{$\begin{array}{l}\text { (Poisson) } \\
\text { Neutrality }\end{array}$} \\
\hline & $(1)$ & $(2)$ & $(3)$ & $(4)$ & $(5)$ & $(6)$ \\
\hline Locality & $\begin{array}{l}-0.05 \\
(0.06)\end{array}$ & $\begin{array}{l}-0.03 \\
(0.07)\end{array}$ & $\begin{array}{c}0.09 \\
(0.06)\end{array}$ & $\begin{array}{c}0.13 \\
(0.07)\end{array}$ & $\begin{array}{l}-0.04 \\
(0.04)\end{array}$ & $\begin{array}{l}-0.05 \\
(0.05)\end{array}$ \\
\hline Exposure & $\begin{array}{c}0.24^{* * *} \\
(0.06)\end{array}$ & $\begin{array}{c}0.26^{* * *} \\
(0.07)\end{array}$ & $\begin{array}{c}0.03 \\
(0.06)\end{array}$ & $\begin{array}{c}0.09 \\
(0.07)\end{array}$ & $\begin{array}{l}0.09^{*} \\
(0.04)\end{array}$ & $\begin{array}{l}0.12^{*} \\
(0.05)\end{array}$ \\
\hline Politicisation & $\begin{array}{l}-0.01 \\
(0.06)\end{array}$ & $\begin{array}{c}0.01 \\
(0.07)\end{array}$ & $\begin{array}{l}-0.03 \\
(0.06)\end{array}$ & $\begin{array}{l}-0.01 \\
(0.07)\end{array}$ & $\begin{array}{c}0.07 \\
(0.04)\end{array}$ & $\begin{array}{c}0.02 \\
(0.05)\end{array}$ \\
\hline Age & & $\begin{array}{c}-0.01^{* * *} \\
(0.003)\end{array}$ & & $\begin{array}{l}0.02^{* * *} \\
(0.003)\end{array}$ & & $\begin{array}{c}-0.01^{* *} \\
(0.002)\end{array}$ \\
\hline Female & & $\begin{array}{l}-0.14 \\
(0.07)\end{array}$ & & $\begin{array}{l}-0.01 \\
(0.08)\end{array}$ & & $\begin{array}{l}0.12^{*} \\
(0.05)\end{array}$ \\
\hline Education & & $\begin{array}{l}-0.01 \\
(0.02)\end{array}$ & & $\begin{array}{c}0.13^{* * *} \\
(0.02)\end{array}$ & & $\begin{array}{c}-0.03^{*} \\
(0.01)\end{array}$ \\
\hline Income & & $\begin{array}{c}0.02 \\
(0.01)\end{array}$ & & $\begin{array}{c}0.09^{* * *} \\
(0.02)\end{array}$ & & $\begin{array}{l}-0.01 \\
(0.01)\end{array}$ \\
\hline Urban-Rural & & $\begin{array}{c}-0.005 \\
(0.04)\end{array}$ & & $\begin{array}{c}0.02 \\
(0.05)\end{array}$ & & $\begin{array}{l}0.001 \\
(0.03)\end{array}$ \\
\hline Years in Canton & & $\begin{array}{l}-0.001 \\
(0.002)\end{array}$ & & $\begin{array}{c}0.01^{*} \\
(0.002)\end{array}$ & & $\begin{array}{l}0.0004 \\
(0.001)\end{array}$ \\
\hline Climate Worries & & $\begin{array}{c}0.52^{* * *} \\
(0.05)\end{array}$ & & $\begin{array}{c}0.07 \\
(0.05)\end{array}$ & & $\begin{array}{c}0.08^{*} \\
(0.04)\end{array}$ \\
\hline Political Interest & & $\begin{array}{c}0.08 \\
(0.04)\end{array}$ & & $\begin{array}{c}1.21^{* * *} \\
(0.05)\end{array}$ & & $\begin{array}{c}-0.27^{* * *} \\
(0.03)\end{array}$ \\
\hline Left-Right & & $\begin{array}{c}-0.09^{* * *} \\
(0.02)\end{array}$ & & $\begin{array}{l}-0.03 \\
(0.02)\end{array}$ & & $\begin{array}{c}-0.005 \\
(0.01)\end{array}$ \\
\hline Constant & & & & & $\begin{array}{c}-0.58^{* * *} \\
(0.04) \\
\end{array}$ & $\begin{array}{c}0.28 \\
(0.19) \\
\end{array}$ \\
\hline $\begin{array}{l}\text { Observations } \\
\text { Log Likelihood } \\
\text { Akaike Inf. Crit. }\end{array}$ & 3,910 & 3,221 & 3,531 & 2,924 & $\begin{array}{c}3,608 \\
-3,679.95 \\
7,367.90\end{array}$ & $\begin{array}{c}2,973 \\
-2,836.78 \\
5,699.56\end{array}$ \\
\hline
\end{tabular}




\section{Complete cases}

The statistics in Table A7 are calculated with data from respondents who answered all related survey questions.

Table A7: Main results — with data from complete cases

\begin{tabular}{|c|c|c|c|c|c|c|}
\hline & \multicolumn{2}{|c|}{ Acceptance } & \multicolumn{2}{|c|}{ Turnout } & \multicolumn{2}{|c|}{ Neutrality } \\
\hline & (1) & $(2)$ & $(3)$ & (4) & $(5)$ & $(6)$ \\
\hline Locality & $\begin{array}{l}-0.05 \\
(0.04)\end{array}$ & $\begin{array}{l}-0.06 \\
(0.04)\end{array}$ & $\begin{array}{l}0.11^{*} \\
(0.05)\end{array}$ & $\begin{array}{c}0.08 \\
(0.04)\end{array}$ & $\begin{array}{l}-0.04 \\
(0.03)\end{array}$ & $\begin{array}{l}-0.03 \\
(0.03)\end{array}$ \\
\hline Exposure & $\begin{array}{c}0.15^{* * *} \\
(0.04)\end{array}$ & $\begin{array}{c}0.14^{* * *} \\
(0.04)\end{array}$ & $\begin{array}{c}0.03 \\
(0.05)\end{array}$ & $\begin{array}{c}0.04 \\
(0.04)\end{array}$ & $\begin{array}{l}0.08^{* *} \\
(0.03)\end{array}$ & $\begin{array}{l}0.07^{* *} \\
(0.03)\end{array}$ \\
\hline Politicisation & $\begin{array}{c}0.01 \\
(0.04)\end{array}$ & $\begin{array}{c}0.01 \\
(0.04)\end{array}$ & $\begin{array}{c}0.03 \\
(0.05)\end{array}$ & $\begin{array}{c}0.02 \\
(0.04)\end{array}$ & $\begin{array}{c}0.01 \\
(0.03)\end{array}$ & $\begin{array}{c}0.01 \\
(0.03)\end{array}$ \\
\hline Age & & $\begin{array}{c}-0.01^{* * *} \\
(0.001)\end{array}$ & & $\begin{array}{l}0.01^{* * *} \\
(0.002)\end{array}$ & & $\begin{array}{c}-0.003^{* * *} \\
(0.001)\end{array}$ \\
\hline Female & & $\begin{array}{l}-0.06 \\
(0.04)\end{array}$ & & $\begin{array}{c}0.04 \\
(0.04)\end{array}$ & & $\begin{array}{c}0.06^{*} \\
(0.03)\end{array}$ \\
\hline Education & & $\begin{array}{l}-0.02 \\
(0.01)\end{array}$ & & $\begin{array}{c}0.06^{* * *} \\
(0.01)\end{array}$ & & $\begin{array}{c}-0.02^{*} \\
(0.01)\end{array}$ \\
\hline Income & & $\begin{array}{c}0.01 \\
(0.01)\end{array}$ & & $\begin{array}{c}0.05^{* * *} \\
(0.01)\end{array}$ & & $\begin{array}{l}-0.01 \\
(0.01)\end{array}$ \\
\hline Urban-Rural & & $\begin{array}{l}-0.03 \\
(0.02)\end{array}$ & & $\begin{array}{l}0.004 \\
(0.03)\end{array}$ & & $\begin{array}{c}0.01 \\
(0.02)\end{array}$ \\
\hline Years in Canton & & $\begin{array}{l}-0.001 \\
(0.001)\end{array}$ & & $\begin{array}{c}0.003^{*} \\
(0.001)\end{array}$ & & $\begin{array}{c}0.0002 \\
(0.001)\end{array}$ \\
\hline Climate Worries & & $\begin{array}{c}0.25^{* * *} \\
(0.03)\end{array}$ & & $\begin{array}{l}0.06^{*} \\
(0.03)\end{array}$ & & $\begin{array}{c}0.05^{*} \\
(0.02)\end{array}$ \\
\hline Political Interest & & $\begin{array}{c}0.02 \\
(0.02)\end{array}$ & & $\begin{array}{c}0.68^{* * *} \\
(0.03)\end{array}$ & & $\begin{array}{c}-0.14^{* * *} \\
(0.02)\end{array}$ \\
\hline Left-Right & & $\begin{array}{c}-0.04^{* * *} \\
(0.01)\end{array}$ & & $\begin{array}{l}-0.01 \\
(0.01)\end{array}$ & & $\begin{array}{c}-0.003 \\
(0.01)\end{array}$ \\
\hline Constant & $\begin{array}{c}3.60^{* * *} \\
(0.04) \\
\end{array}$ & $\begin{array}{c}3.42^{* * *} \\
(0.15) \\
\end{array}$ & $\begin{array}{c}3.88^{* * *} \\
(0.05) \\
\end{array}$ & $\begin{array}{c}0.74^{* * *} \\
(0.17) \\
\end{array}$ & $\begin{array}{c}0.52^{* * *} \\
(0.03) \\
\end{array}$ & $\begin{array}{c}1.02^{* * *} \\
(0.11) \\
\end{array}$ \\
\hline Observations & 2,881 & 2,881 & 2,881 & 2,881 & 2,881 & 2,881 \\
\hline $\mathrm{R}^{2}$ & 0.01 & 0.07 & 0.002 & 0.29 & 0.004 & 0.06 \\
\hline
\end{tabular}




\section{Canton fixed effects}

The regression models in Table A8 include fixed-effects for the respondent's canton of residence.

Table A8: Main results — with canton fixed effects

\begin{tabular}{|c|c|c|c|c|c|c|}
\hline & \multicolumn{2}{|c|}{ Acceptance } & \multicolumn{2}{|c|}{ Turnout } & \multicolumn{2}{|c|}{ Neutrality } \\
\hline & $(1)$ & $(2)$ & $(3)$ & $(4)$ & $(5)$ & $(6)$ \\
\hline Locality & $\begin{array}{l}-0.04 \\
(0.03)\end{array}$ & $\begin{array}{l}-0.03 \\
(0.03)\end{array}$ & $\begin{array}{c}0.07 \\
(0.04)\end{array}$ & $\begin{array}{c}0.08 \\
(0.04)\end{array}$ & $\begin{array}{l}-0.02 \\
(0.03)\end{array}$ & $\begin{array}{l}-0.03 \\
(0.03)\end{array}$ \\
\hline Exposure & $\begin{array}{c}0.13^{* * *} \\
(0.03)\end{array}$ & $\begin{array}{c}0.12^{* * *} \\
(0.03)\end{array}$ & $\begin{array}{c}0.03 \\
(0.04)\end{array}$ & $\begin{array}{c}0.05 \\
(0.04)\end{array}$ & $\begin{array}{l}0.05^{*} \\
(0.03)\end{array}$ & $\begin{array}{l}0.07^{*} \\
(0.03)\end{array}$ \\
\hline Politicisation & $\begin{array}{c}0.01 \\
(0.03)\end{array}$ & $\begin{array}{c}0.02 \\
(0.03)\end{array}$ & $\begin{array}{c}0.01 \\
(0.04)\end{array}$ & $\begin{array}{c}0.02 \\
(0.04)\end{array}$ & $\begin{array}{c}0.04 \\
(0.03)\end{array}$ & $\begin{array}{c}0.01 \\
(0.03)\end{array}$ \\
\hline Age & & $\begin{array}{c}-0.01^{* * *} \\
(0.001)\end{array}$ & & $\begin{array}{l}0.01^{* * *} \\
(0.002)\end{array}$ & & $\begin{array}{c}-0.003^{* *} \\
(0.001)\end{array}$ \\
\hline Female & & $\begin{array}{l}-0.06 \\
(0.04)\end{array}$ & & $\begin{array}{c}0.05 \\
(0.04)\end{array}$ & & $\begin{array}{c}0.06^{*} \\
(0.03)\end{array}$ \\
\hline Education & & $\begin{array}{l}-0.02 \\
(0.01)\end{array}$ & & $\begin{array}{c}0.06^{* * *} \\
(0.01)\end{array}$ & & $\begin{array}{c}-0.02^{*} \\
(0.01)\end{array}$ \\
\hline Income & & $\begin{array}{c}0.01 \\
(0.01)\end{array}$ & & $\begin{array}{c}0.06^{* * *} \\
(0.01)\end{array}$ & & $\begin{array}{l}-0.01 \\
(0.01)\end{array}$ \\
\hline Urban-Rural & & $\begin{array}{l}-0.03 \\
(0.02)\end{array}$ & & $\begin{array}{c}-0.003 \\
(0.03)\end{array}$ & & $\begin{array}{c}0.01 \\
(0.02)\end{array}$ \\
\hline Years in Canton & & $\begin{array}{l}-0.001 \\
(0.001)\end{array}$ & & $\begin{array}{l}0.003^{*} \\
(0.001)\end{array}$ & & $\begin{array}{l}0.0001 \\
(0.001)\end{array}$ \\
\hline Climate Worries & & $\begin{array}{c}0.26^{* * *} \\
(0.02)\end{array}$ & & $\begin{array}{c}0.06^{*} \\
(0.03)\end{array}$ & & $\begin{array}{c}0.04^{*} \\
(0.02)\end{array}$ \\
\hline Political Interest & & $\begin{array}{c}0.02 \\
(0.02)\end{array}$ & & $\begin{array}{c}0.70^{* * *} \\
(0.03)\end{array}$ & & $\begin{array}{c}-0.15^{* * *} \\
(0.02)\end{array}$ \\
\hline Left-Right & & $\begin{array}{c}-0.05^{* * *} \\
(0.01)\end{array}$ & & $\begin{array}{l}-0.01 \\
(0.01)\end{array}$ & & $\begin{array}{c}-0.004 \\
(0.01)\end{array}$ \\
\hline Constant & $\begin{array}{c}3.51^{* * *} \\
(0.06) \\
\end{array}$ & $\begin{array}{c}3.26^{* * *} \\
(0.15)\end{array}$ & $\begin{array}{c}3.78^{* * *} \\
(0.08)\end{array}$ & $\begin{array}{l}0.55^{* *} \\
(0.18) \\
\end{array}$ & $\begin{array}{c}0.51^{* * *} \\
(0.05) \\
\end{array}$ & $\begin{array}{c}1.04^{* * *} \\
(0.11)\end{array}$ \\
\hline Canton FEs & Yes & Yes & Yes & Yes & Yes & Yes \\
\hline Observations & 3,910 & 3,221 & 3,531 & 2,924 & 3,608 & 2,973 \\
\hline $\mathrm{R}^{2}$ & 0.01 & 0.08 & 0.02 & 0.31 & 0.01 & 0.07 \\
\hline
\end{tabular}

Note: $\quad{ }^{*} \mathrm{p}<0.05 ;{ }^{* *} \mathrm{p}<0.01 ;{ }^{* * *} \mathrm{p}<0.001$ 


\section{Commune fixed effects}

The regression models in Table A9 include fixed-effects for the respondent's commune of residence.

Table A9: Main results — with municipality fixed effects

\begin{tabular}{|c|c|c|c|c|c|c|}
\hline & \multicolumn{2}{|c|}{ Acceptance } & \multicolumn{2}{|c|}{ Turnout } & \multicolumn{2}{|c|}{ Neutrality } \\
\hline & $(1)$ & $(2)$ & $(3)$ & $(4)$ & $(5)$ & $(6)$ \\
\hline Locality & $\begin{array}{l}-0.02 \\
(0.04)\end{array}$ & $\begin{array}{l}-0.03 \\
(0.04)\end{array}$ & $\begin{array}{c}0.09 \\
(0.05)\end{array}$ & $\begin{array}{l}0.10^{*} \\
(0.05)\end{array}$ & $\begin{array}{l}-0.04 \\
(0.03)\end{array}$ & $\begin{array}{l}-0.04 \\
(0.03)\end{array}$ \\
\hline Exposure & $\begin{array}{c}0.13^{* * *} \\
(0.04)\end{array}$ & $\begin{array}{l}0.12^{* *} \\
(0.04)\end{array}$ & $\begin{array}{c}0.01 \\
(0.05)\end{array}$ & $\begin{array}{c}0.02 \\
(0.05)\end{array}$ & $\begin{array}{l}0.07^{*} \\
(0.03)\end{array}$ & $\begin{array}{l}0.07^{*} \\
(0.03)\end{array}$ \\
\hline Politicisation & $\begin{array}{c}0.02 \\
(0.04)\end{array}$ & $\begin{array}{c}0.02 \\
(0.04)\end{array}$ & $\begin{array}{l}-0.03 \\
(0.05)\end{array}$ & $\begin{array}{l}-0.03 \\
(0.05)\end{array}$ & $\begin{array}{c}0.04 \\
(0.03)\end{array}$ & $\begin{array}{l}0.005 \\
(0.03)\end{array}$ \\
\hline Age & & $\begin{array}{c}-0.01^{* * *} \\
(0.002)\end{array}$ & & $\begin{array}{l}0.01^{* * *} \\
(0.002)\end{array}$ & & $\begin{array}{l}-0.002 \\
(0.001)\end{array}$ \\
\hline Female & & $\begin{array}{l}-0.08 \\
(0.04)\end{array}$ & & $\begin{array}{c}0.01 \\
(0.06)\end{array}$ & & $\begin{array}{c}0.03 \\
(0.03)\end{array}$ \\
\hline Education & & $\begin{array}{l}-0.01 \\
(0.01)\end{array}$ & & $\begin{array}{c}0.06^{* * *} \\
(0.02)\end{array}$ & & $\begin{array}{l}-0.02 \\
(0.01)\end{array}$ \\
\hline Income & & $\begin{array}{c}0.01 \\
(0.01)\end{array}$ & & $\begin{array}{c}0.05^{* * *} \\
(0.01)\end{array}$ & & $\begin{array}{l}-0.01 \\
(0.01)\end{array}$ \\
\hline Urban-Rural & & $\begin{array}{l}-0.07 \\
(0.16)\end{array}$ & & $\begin{array}{c}0.09 \\
(0.20)\end{array}$ & & $\begin{array}{l}-0.04 \\
(0.12)\end{array}$ \\
\hline Years in Canton & & $\begin{array}{l}-0.001 \\
(0.001)\end{array}$ & & $\begin{array}{c}0.003^{*} \\
(0.002)\end{array}$ & & $\begin{array}{l}-0.001 \\
(0.001)\end{array}$ \\
\hline Climate Worries & & $\begin{array}{c}0.27^{* * *} \\
(0.03)\end{array}$ & & $\begin{array}{c}0.03 \\
(0.04)\end{array}$ & & $\begin{array}{c}0.05^{*} \\
(0.02)\end{array}$ \\
\hline Political Interest & & $\begin{array}{c}0.001 \\
(0.03)\end{array}$ & & $\begin{array}{c}0.68^{* * *} \\
(0.03)\end{array}$ & & $\begin{array}{c}-0.17^{\text {**** }} \\
(0.02)\end{array}$ \\
\hline Left-Right & & $\begin{array}{c}-0.05^{* * *} \\
(0.01)\end{array}$ & & $\begin{array}{l}-0.01 \\
(0.01)\end{array}$ & & $\begin{array}{c}0.01 \\
(0.01)\end{array}$ \\
\hline Constant & $\begin{array}{c}4.18^{* * *} \\
(0.33) \\
\end{array}$ & $\begin{array}{c}3.94^{* * *} \\
(0.49)\end{array}$ & $\begin{array}{c}4.34^{* * *} \\
(0.46)\end{array}$ & $\begin{array}{l}1.30^{*} \\
(0.62) \\
\end{array}$ & $\begin{array}{c}0.36 \\
(0.27) \\
\end{array}$ & $\begin{array}{l}1.01^{* *} \\
(0.38) \\
\end{array}$ \\
\hline Commune FEs & Yes & Yes & Yes & Yes & Yes & Yes \\
\hline Observations & 3,910 & 3,221 & 3,531 & 2,924 & 3,608 & 2,973 \\
\hline $\mathrm{R}^{2}$ & 0.36 & 0.43 & 0.37 & 0.55 & 0.35 & 0.43 \\
\hline
\end{tabular}

Note: $\quad{ }^{*} \mathrm{p}<0.05 ;{ }^{* *} \mathrm{p}<0.01 ;{ }^{* * *} \mathrm{p}<0.001$ 


\section{Excluding manipulation check failures}

The statistics in Table A10 are calculated with data from respondents who passed the factual manipulation check.

Table A10: Main results — manipulation check failures excluded

\begin{tabular}{|c|c|c|c|c|c|c|}
\hline & \multicolumn{2}{|c|}{ Acceptance } & \multicolumn{2}{|c|}{ Turnout } & \multicolumn{2}{|c|}{ Neutrality } \\
\hline & $(1)$ & $(2)$ & $(3)$ & $(4)$ & $(5)$ & $(6)$ \\
\hline Locality & $\begin{array}{l}-0.03 \\
(0.04)\end{array}$ & $\begin{array}{l}-0.04 \\
(0.04)\end{array}$ & $\begin{array}{c}0.06 \\
(0.05)\end{array}$ & $\begin{array}{c}0.06 \\
(0.05)\end{array}$ & $\begin{array}{l}-0.03 \\
(0.03)\end{array}$ & $\begin{array}{l}-0.05 \\
(0.03)\end{array}$ \\
\hline Exposure & $\begin{array}{l}0.11^{* *} \\
(0.04)\end{array}$ & $\begin{array}{l}0.12^{* *} \\
(0.04)\end{array}$ & $\begin{array}{l}0.003 \\
(0.05)\end{array}$ & $\begin{array}{c}0.05 \\
(0.05)\end{array}$ & $\begin{array}{c}0.05 \\
(0.03)\end{array}$ & $\begin{array}{c}0.05 \\
(0.03)\end{array}$ \\
\hline Politicisation & $\begin{array}{l}-0.01 \\
(0.04)\end{array}$ & $\begin{array}{c}0.01 \\
(0.04)\end{array}$ & $\begin{array}{c}0.01 \\
(0.05)\end{array}$ & $\begin{array}{l}-0.02 \\
(0.05)\end{array}$ & $\begin{array}{c}0.04 \\
(0.03)\end{array}$ & $\begin{array}{c}0.02 \\
(0.03)\end{array}$ \\
\hline Age & & $\begin{array}{c}-0.005^{* *} \\
(0.002)\end{array}$ & & $\begin{array}{c}0.01^{* *} \\
(0.002)\end{array}$ & & $\begin{array}{c}-0.003^{*} \\
(0.001)\end{array}$ \\
\hline Female & & $\begin{array}{l}-0.08 \\
(0.04)\end{array}$ & & $\begin{array}{l}-0.01 \\
(0.05)\end{array}$ & & $\begin{array}{c}0.05 \\
(0.03)\end{array}$ \\
\hline Education & & $\begin{array}{l}-0.02 \\
(0.01)\end{array}$ & & $\begin{array}{c}0.06^{* * *} \\
(0.01)\end{array}$ & & $\begin{array}{c}-0.02^{* *} \\
(0.01)\end{array}$ \\
\hline Income & & $\begin{array}{c}0.01 \\
(0.01)\end{array}$ & & $\begin{array}{c}0.04^{* * *} \\
(0.01)\end{array}$ & & $\begin{array}{l}-0.01 \\
(0.01)\end{array}$ \\
\hline Urban-Rural & & $\begin{array}{l}-0.02 \\
(0.03)\end{array}$ & & $\begin{array}{c}-0.002 \\
(0.03)\end{array}$ & & $\begin{array}{c}0.01 \\
(0.02)\end{array}$ \\
\hline Years in Canton & & $\begin{array}{l}-0.001 \\
(0.001)\end{array}$ & & $\begin{array}{c}0.002 \\
(0.001)\end{array}$ & & $\begin{array}{l}0.0001 \\
(0.001)\end{array}$ \\
\hline Climate Worries & & $\begin{array}{c}0.23^{* * *} \\
(0.03)\end{array}$ & & $\begin{array}{c}0.03 \\
(0.03)\end{array}$ & & $\begin{array}{l}0.06^{* *} \\
(0.02)\end{array}$ \\
\hline Political Interest & & $\begin{array}{c}0.02 \\
(0.03)\end{array}$ & & $\begin{array}{c}0.71^{* * *} \\
(0.03)\end{array}$ & & $\begin{array}{c}-0.17^{* * *} \\
(0.02)\end{array}$ \\
\hline Left-Right & & $\begin{array}{c}-0.05^{* * *} \\
(0.01)\end{array}$ & & $\begin{array}{l}-0.01 \\
(0.01)\end{array}$ & & $\begin{array}{c}0.002 \\
(0.01)\end{array}$ \\
\hline Constant & $\begin{array}{c}3.60^{* * *} \\
(0.04) \\
\end{array}$ & $\begin{array}{c}3.47^{* * *} \\
(0.17) \\
\end{array}$ & $\begin{array}{c}4.01^{* * *} \\
(0.05) \\
\end{array}$ & $\begin{array}{c}1.15^{* * *} \\
(0.20)\end{array}$ & $\begin{array}{c}0.54^{* * *} \\
(0.03) \\
\end{array}$ & $\begin{array}{c}1.07^{* * *} \\
(0.13) \\
\end{array}$ \\
\hline $\begin{array}{l}\text { Observations } \\
\mathrm{R}^{2}\end{array}$ & $\begin{array}{l}2,730 \\
0.003\end{array}$ & $\begin{array}{c}2,295 \\
0.07\end{array}$ & $\begin{array}{c}2,449 \\
0.0005\end{array}$ & $\begin{array}{c}2,069 \\
0.29\end{array}$ & $\begin{array}{l}2,494 \\
0.002\end{array}$ & $\begin{array}{c}2,100 \\
0.07\end{array}$ \\
\hline
\end{tabular}

Note: $\quad{ }^{*} \mathrm{p}<0.05 ;{ }^{* *} \mathrm{p}<0.01 ;{ }^{* * *} \mathrm{p}<0.001$ 


\section{Questionnaire}

1. Which canton and commune do you live in?

- Aargau [1] - Zürich [26]

- Aarau [1] - Zürich [2212]

2. How long have you been living in this canton?

- 0 - 111 years

3. Please indicate your gender.

- Male [1]

- Female [2]

- Other [3]

4. Please indicate your year of birth.

- 1908 [111] - 2001 [18]

[Additional questions for a separate study]

5. What is the highest level of education that you have already completed?

- Incomplete compulsory school/primary school [1]

- Compulsory school [2]

- Transitional educational programme [3]

- General training without maturity [4]

- Elementary vocational training or apprenticeship [5]

- Maturity or teacher training school [6]

- Post-secondary education, non tertiary [7]

- Vocational high school with federal or master certificate [8] 
- University of applied science, university, ETH [9]

- Doctorate, habilitation [10]

- Don’t know [9999]

6. How worried are you about climate change?

- Very worried [4]

- Somewhat worried [3]

- Not very worried [2]

- Not at all worried [1]

- Don't know [9999]

7. How interested are you in politics?

- Very interested [4]

- Somewhat interested [3]

- Not very interested [2]

- Not at all interested [1]

- Don't know [9999]

8. In politics people sometimes talk of 'left' and 'right.' Where would you place yourself on the scale below, where 0 means the left and 10 means the right?

- $0[0]-10[10]$

9. To increase the amount of electricity generated from renewable sources of energy, there are proposals to place wind turbines in the canton of [own / different canton], in landscapes similar to the one pictured below.

[Photograph with / without a wind turbine]

There has been a mixed reaction to these proposals. Some ['people' / 'political parties, 
such as the Social Democratic Party of Switzerland,'] support these proposals while other ['people' / 'political parties, such as the Swiss People's Party,'] oppose them.

How about you? Do you support or oppose these wind turbine proposals?

- Strongly support [5]

- Support [4]

- Neither support nor oppose [3]

- Oppose [2]

- Strongly oppose [1]

- Don’t know [9999]

10. [Randomly insert $a, b$, or $c]$

a. Which of the following best describes the landscape photograph that you have seen in the previous question?

- It included no wind turbines. [0/1, depending on the vignette]

- It included one wind turbine. [0/1, depending on the vignette]

- It included two wind turbines. [0]

- Don't know [0]

b. Which location was referenced in the text about wind turbines that you have read in the previous question? [Randomise the order of the answer categories, except 'Don't know']

- [own canton $][0 / 1$, depending on the vignette]

- $[$ different canton $][0 / 1$, depending on the vignette]

- $[$ another canton $][0]$

- Don't know [0]

c. According to the text about wind turbines that you have read in the previous screen, which one of the following actors have disagreements over wind turbine proposals? [Randomise the order of the answer categories, except 'Don't know'] 
- People [0/1, depending on the vignette]

- Political parties [0/1, depending on the vignette]

- Energy companies [0]

- Don't know [0]

11. The Swiss federal election is being held on 20 October 2019. How likely is that you will vote?

- Very likely [5]

- Fairly likely [4]

- Neither likely nor unlikely [3]

- Fairly unlikely [2]

- Very unlikely [1]

- Don't know [9999]

- I am not eligible to vote [-9999]

[Show if $q 11 !=-9999 ;$ randomise the order of questions; show both $q 12$ and $q 13$ ]

12. How likely is it that you will vote for the Social Democratic Party of Switzerland?

- Very likely [5]

- Fairly likely [4]

- Neither likely nor unlikely [3]

- Fairly unlikely [2]

- Very unlikely [1]

- Don't know [9999]

13. How likely is it that you will vote for the Swiss People's Party?

- Very likely [5]

- Fairly likely [4]

- Neither likely nor unlikely [3]

- Fairly unlikely [2] 
- Very unlikely [1]

- Don't know [9999]

[Additional questions for a separate study]

14. What is the gross annual income of your household? Please include all income of all persons who contribute to the maintenance. Count not only wages, but also any other income.

- Less than CHF 33,000 [1]

- $\mathrm{CHF} 33,000$ - CHF 48,999 [2]

- $\mathrm{CHF} 49,000$ - CHF 61,999 [3]

- $\mathrm{CHF} 62,000$ - CHF 74,999 [4]

- $\mathrm{CHF} 75,000$ - CHF 87,999 [5]

- CHF 88,000 - CHF 103,999 [6]

- CHF 104,000 - CHF 121,999 [7]

- CHF 122,000 - CHF 145,999 [8]

- CHF 146,000 - CHF 186,999 [9]

- CHF 187,000 or more [10]

- Don't know [9999] 


\section{References}

Brookes, S. T., Whitely, E., Egger, M., Smith, G. D., Mulheran, P. A., and Peters, T. J. (2004). Subgroup analyses in randomized trials: Risks of subgroup-specific analyses;: Power and sample size for the interaction test. Journal of Clinical Epidemiology, 57(3), 229-236.

Burke, J. F., Sussman, J. B., Kent, D. M., and Hayward, R. A. (2015). Three simple rules to ensure reasonably credible subgroup analyses. $B M J, 351,1-5$. 


\section{Pre-Analysis Plan for a Survey Experiment on Wind Turbines*}

\section{Summary}

This report specifies our plan for a survey experiment on how people respond to proposals for new wind turbines. The experiment is based on a random assignment of subjects to one of the eight versions of a vignette - a text with an image about proposals - in a $2 x 2 \times 2$, full-factorial design. We will use this experiment to test the effect of three factors-project locality, turbine exposure, and issue politicisation - on public acceptance and electoral behaviour.

\section{Motivation}

There is a widespread public support for wind energy in general. Research shows that, for example, over $70 \%$ of Canadians (Sherren, Parkins, Owen, and Terashima, 2019) and more than $80 \%$ of Americans (Klick and Smith, 2010) are in favour of this energy source. Yet, wind turbine proposals attract a considerable amount of public opposition (Firestone and Kempton, 2007; Pasqualetti, Gipe, and Righter, 2002) although, with exposure, people seem to warm to turbines after a while (Wolsink, 2007). Many explain this contrast, of support and opposition, with reference to general against local (Devine-Wright, 2009; Wolsink, 2006) and urban against rural (Hirsh and Sovacool, 2013) attitudes.

At the same time, energy issues (Jeong and Lowry, 2019; Kuzemko, 2016), and particularly the siting of wind turbines (Bues and Gailing, 2016), have remained relatively depoliticised until recently. However, there are signs of change. Jeong and Lowry (2019), for example, show that energy policy is becoming an increasingly politicised issue in the U.S. Congress.

\footnotetext{
${ }^{*}$ This is an anonymised version of the pre-analysis plan for the article titled 'Wind Turbines, Public Acceptance, and Electoral Outcomes', registered at egap.org on 3 September 2019-before data collection.
} 
Against this background, we seek to answer three questions in this project. 1. Do (a) the locality of a proposed wind turbine project, (b) visual exposure to a turbine, and/or (c) the politicisation of the overall issue have a causal effect on the public acceptance of wind turbines?

Much of what we know about the public acceptance of wind turbines originates from surveys research, unable to establish causal links. In addition locality and exposure - two of the most important factors according to the existing literature - we will analyse the effect of politicisation on public acceptance in an experimental design.

2. Do these three factors have effects on electoral behaviour?

Efforts to de- and re-politicise energy issues suggest that wind turbine proposals might have electoral consequences. Indeed, Stokes (2016) shows that there are such consequences at the aggregate level: electoral turnout increases and government vote share decreases in precincts with, or close to, a wind turbine. In our experiment we will look for electoral consequences at the individual level, and analyse the effect of not only locality but also exposure and politicisation.

3. Do the effects of these three factors differ between rural and urban populations?

There might be a rural-urban divide in attitudes towards wind turbines (Hirsh and Sovacool, 2013), but this is a claim in need of empirical evidence. In fact, Stokes (2016) finds that reaction to wind turbines is very much the same in all precincts, rural or otherwise. That is why testing whether the effects are heterogeneous across rural-urban residents is another motivation for our study.

\section{Design}

We will conduct a factorial survey experiment in September 2019 in Switzerland. After a series of questions on demographics and attitudes, subjects will be randomly assigned to one of the eight versions of a vignette - the treatment. The survey will then continue with our outcome measures and a manipulation check. We will place an income question at the end of the survey, which will also include additional questions for a separate study. The English version of the related part of the questionnaire is in the Appendix. 


\section{Switzerland}

Switzerland is a multilingual and federal state. The national languages are German, French, Italian, and Romansh. We will translate our questionnaire into the first three languages before scripting the survey in Qualtrics (www.qualtrics.com). We will not translate it into Romansh because too few people - less than $1 \%$ of the population - speak this language.

The Swiss Confederation is composed of 26 cantons - each with their own constitution, parliament, government, police, and courts. In addition to the national and communal identities, there is a strong sense of cantonal identity in Switzerland (Kriesi and Trechsel, 2008, pp. 10-16). For the experimental variation in locality, we will use the cantons to name the locations for wind turbine proposals in our treatments.

Below the level of cantons, there are currently 2212 communes. The Federal Statistical Office (www.bfs.admin.ch) classifies these communes into three as rural (about 22\% of all communes), intermediate (26\%), and urban (52\%) areas. Several factors play a role in this classification, and these include not only population density but also overnight stays and employment (Kohler and Goebel, 2014). We will use this classification for the sub-group analysis of rural-urban populations. According to our calculations, about $63 \%$ of the population in Switzerland live in urban communes, $21 \%$ in intermediate communes, and the remaining $16 \%$ in rural communes.

Wind energy has a negligible share in the overall electricity mix in Switzerland: in 2017, wind turbines accounted for only $0.02 \%$ of the electricity produced in Switzerland, in comparison to $7.5 \%$ in Austria and 12.9\% in Germany. However, the Energy Strategy 2050, which was approved in a referendum on 21 May 2017, envisages an over 40-fold increase in wind energy in the next three decades, with up to 1,000 new wind turbines to be erected all over the country.

Switzerland will hold federal elections this year on 20 October 2019. Overall, wind energy is not one of the contested issues in the campaign. However, the two parties with clearest positions on wind energy are the Social Democratic Party of Switzerland, which supports wind turbine proposals, and the Swiss People's Party, which opposes them. We will use these two parties in our experimental treatments. They are the largest two parties in Switzerland at least since 1999, currently represented by two Councillors each in the federal government. 
We aim to field the survey as close to the federal elections as possible while completing the data collection process before the first postal votes are cast. As voting papers are sent to voters three to four weeks before each election, the end date for our survey will be on or before 22 September 2019 .

\section{Sample}

We will obtain a sample of 4000 subjects from respondi (www.respondi.com). All subjects will be residents of Switzerland. The sample will be stratified by age, gender, canton, and rural-urban classification. We will seek a nationally representative sample according to all these criteria, except the rural-urban classification. Here, we will oversample the subjects from rural and intermediate communes to increase the precision of our sub-group estimates.

\section{Pre-treatment covariates}

Before introducing the experimental component, the survey will collect demographic information on subjects' canton, years lived in that canton, commune, gender, birth year, education. It will also have three attitudinal questions, regarding subjects' worries about climate change, interest in politics, and their left-right self placement.

We will use the question on canton of residence to create the locality factor. All remaining covariates will be used to adjust our estimates. To do so, we will first recode (a) the commune variable as rural, intermediate, or urban according to the classification from the Federal Statistical Office and (b) the birth year variable in terms of age in 2019 .

We will also collect information on household income to adjust the estimates accordingly, but the related question will appear at the end of the survey.

\section{Treatment}

To be able to test the effect of three factors in a single study, we will use a factorial survey experiment (Auspurg and Hinz, 2014). The experiment will be based on a random assignment of subjects to one of the eight versions of a vignette, resulting from crossing three factors (locality, exposure, and politicisation), each with two levels. We provide the vignette structure below. 
To increase the amount of electricity generated from renewable sources of energy, there are proposals to place wind turbines in the canton of [locality: own / different canton], in landscapes similar to the one pictured below.

[exposure: photograph with / without a wind turbine]

There has been a mixed reaction to these proposals. Some [politicisation: 'people' / 'political parties, such as the Social Democratic Party of Switzerland'], support these proposals while other [politicisation: 'people' / 'political parties, such as the Swiss People's Party'], oppose them.

Locality varies whether the vignette mentions the name of (a) the subjects' own canton or (b) a different canton as the location of proposed wind turbines. The latter will be chosen randomly, among the remaining 25 cantons, after subjects' own canton is excluded.

The vignette will have not only a text but also a photograph. Exposure varies whether there is a wind turbine in the photograph or not, as shown in Figure P1. The photograph with the wind turbine is the original, taken in the canton of Lucerne in Switzerland. We have digitally removed the turbine from this landscape, and the resulting photograph is the one on the right in Figure P1. Politicisation varies whether the vignette mentions that there is a disagreement among (a) the people or (b) political parties about wind turbine proposals. This follows the design in Boudreau and MacKenzie (2014).

\section{Post-treatment measures}

Below we list the post-treatment measures that we will analyse as dependent variables. For Acceptance, Turnout, Supporting Vote, and Opposing Vote, we will recode the 'Don't know' answers as missing, otherwise keeping the coding scheme of the related survey questions provided in the Appendix. For Neutrality, our preferred coding scheme is to count the number of questions that subjects answer as 'Neither likely not unlikely' or 'Don't know'. However, we reserve the right to explore alternative coding of this variable, such as counting only 'Neither likely not unlikely' or only 'Don't know' as Neutrality. We will indicate any such alternative analysis as exploratory. 

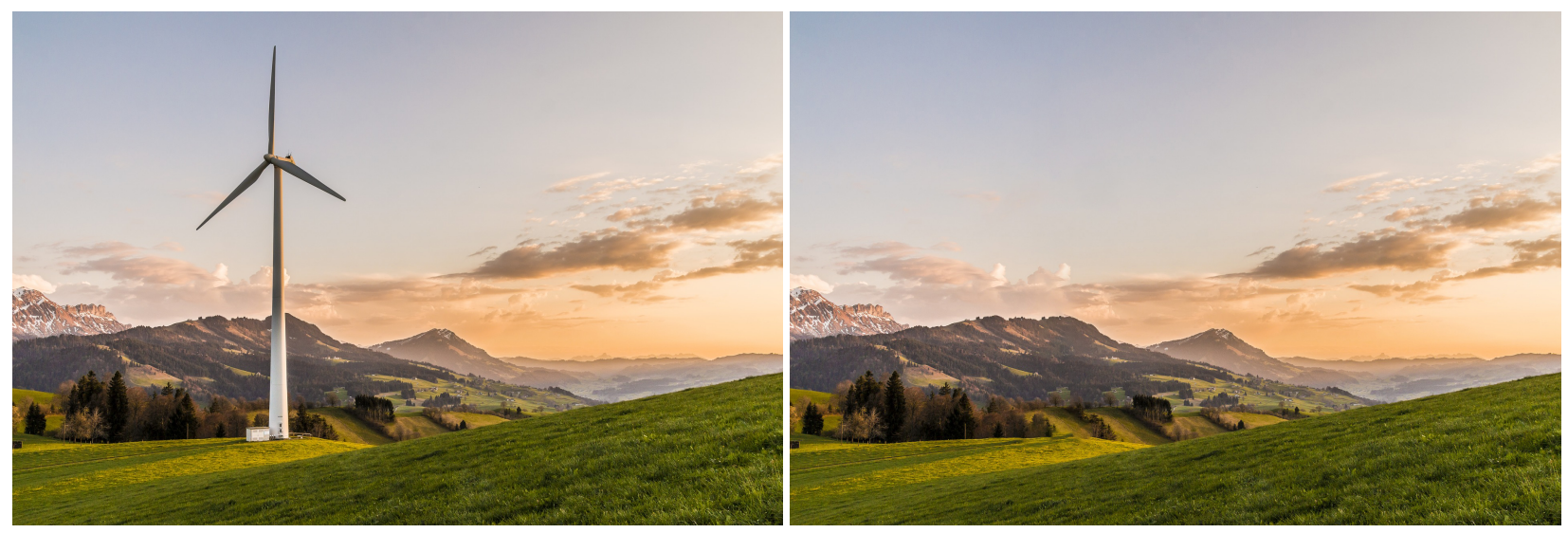

Figure P1: Two versions of a landscape in the canton of Lucerne, Switzerland. On the left, the original photograph of a wind turbine in the commune of Entlebuch. On the right, the digitally altered version without the turbine.

We will limit the analysis of the post-treatment measures of electoral outcomes-Turnout, Supporting Vote, Opposing Vote, and Neutrality - to those subjects who are eligible to vote in the 2019 Swiss federal elections.

\begin{tabular}{|c|c|c|c|}
\hline Outcome & Question(s) & Range & Detail \\
\hline \multirow[t]{2}{*}{ Acceptance } & Do you support or oppose & {$[1,5]$} & Recode 'Don't \\
\hline & these wind turbine proposals? & & know' as missing \\
\hline \multirow[t]{4}{*}{ Turnout } & The Swiss federal election is & {$[1,5]$} & Recode 'Don't \\
\hline & being held on 20 October & & know' as missing \\
\hline & 2019. How likely is that you & & \\
\hline & will vote? & & \\
\hline \multirow[t]{3}{*}{ Supporting Vote } & How likely is it that you will & {$[1,5]$} & Recode 'Don't \\
\hline & vote for the Social & & know' as missing \\
\hline & Democratic Party of & & \\
\hline
\end{tabular}




\begin{tabular}{|c|c|c|c|}
\hline Outcome & Question(s) & Range & Detail \\
\hline \multirow[t]{3}{*}{ Opposing Vote } & How likely is it that you will & {$[1,5]$} & Recode 'Don't \\
\hline & vote for the Swiss People's & & know' as missing \\
\hline & Party? & & \\
\hline \multirow[t]{5}{*}{ Neutrality } & How likely is it that you will & {$[0,2]$} & Count the number \\
\hline & vote for ... (1) the Social & & of questions \\
\hline & Democratic Party of & & answered as \\
\hline & Switzerland? ... (2) the & & 'Neither ...' [3] or \\
\hline & Swiss People's Party? & & 'Don’t know' [9999] \\
\hline
\end{tabular}

The survey question that measures Acceptance will appear on the same screen as the vignette. This is because a screen with no question to answer might encourage subjects to skip the vignette quickly. The remaining questions on electoral behaviour will appear after a manipulation check.

\section{Manipulation Check}

For a factual manipulation check on respondent attentiveness (Kane and Barabas, 2019), the survey includes three questions - one for each factor in the vignette, as to (1) the number of turbines in the photograph, (2) proposed location of the turbines, and (3) the actors mentioned as having disagreements over the proposals. Subjects will see only one of these questions, randomly selected. Each question will have one correct answer. We will report the results from the manipulation check.

\section{Analysis}

Our analysis will be based on three estimates of interest: (1) average marginal component effects (AMCEs), (2) average component interaction effects (ACIEs), and conditional marginal means (CMMs). With these estimates, we will test several hypotheses, detailed below. Overall, we expect that factors that decrease Acceptance should also decrease Neutrality, but they should increase Turnout. This overall expectation follows from the link between opposition to (local) projects and increased political participation (Mansfield, Van Houtven, and Huber, 2001). We also expect that 
whether and how much the support for and/or opposition to wind turbine proposals affect vote choice for a party should depend on voters' awareness of the position of that party on such proposals.

\section{Main Effects: AMCEs}

In factorial survey experiments, one causal quantity of interest is AMCEs (Auspurg and Hinz, 2014; Hainmueller, Hopkins, and Yamamoto, 2014). These measure the effect of a given level of a factor (e.g., locality: own canton) on an outcome (e.g., acceptance), compared to a baseline level of that factor (i.e., locality: different canton), averaged across all other factors (e.g., exposure, but also, where available, covariates) and across all respondents.

With AMCEs, we will test the following hypotheses:

- Acceptance

- decreases if wind turbines are proposed for one's own canton.

- increases with visual exposure to wind turbines.

- decreases with politicisation.

- Turnout

- increases if wind turbines are proposed for one's own canton.

- decreases with visual exposure to wind turbines.

- increases with politicisation.

- Neutrality

- decreases if they are proposed for one's own canton.

- increases with visual exposure to wind turbines.

- decreases with politicisation.

\section{Interaction Effects: ACIEs}

The effect of a given level of a factor on an outcome could depend on the levels of another factor. For example, we expect that the effect of politicisation on vote choice should depend on factors that increases or decreases support for wind turbines in the first place. This is why we will estimate ACIEs (Auspurg and Hinz, 2014; Hainmueller et al., 2014), for interactions between locality and politicisation as well as between exposure and politicisation. 
By estimating these ACIEs, we will test the following hypotheses:

- Supporting Vote

- decreases if (a) wind turbines are proposed for one's own canton and (b) the party in question supports these proposals.

- increases if (a) people are exposed to wind turbines and (b) the party in question supports the proposals.

- Opposing Vote

- increases if (a) wind turbines are proposed for one's own canton and (b) the party in question opposes the proposals.

- decreases if (a) people are exposed to wind turbines and (b) the party in question opposes the proposals.

We expect our design to be likely severely underpowered to detect interaction effects - unless the effect sizes are fairly large and other conditions are favourable. This is why we include Neutrality as an outcome measure of vote choice, which does not require estimating interactions. We will mention this problem and report a power analysis in the article.

\section{Sub-group Analysis: CMMs}

Finally, to test the claim that attitudes to wind turbines differ from rural to urban populations, we will conduct a sub-group analysis for respondents from three classes of Swiss communes: rural, intermediate, and urban. Here we will follow Leeper, Hobolt, and Tilley (2019), and conduct our analysis over CMMs. Here our overall hypothesis is that there are meaningful differences between these sub-groups such that the expected effects above are larger for the residents in rural communes than in intermediate and especially in urban communes. 


\section{References}

Auspurg, K., and Hinz, T. (2014). Factorial survey experiments. London: Sage.

Boudreau, C., and MacKenzie, S. A. (2014). Informing the electorate? How party cues and policy information affect public opinion about initiatives. American Journal of Political Science, 58(1), $48-62$.

Bues, A., and Gailing, L. (2016). Energy transitions and power: Between governmentality and depoliticization. In L. Gailing and T. Moss (Eds.), Conceptualizing Germany's energy transition (pp. 69-91). London: Palgrave.

Devine-Wright, P. (2009). Rethinking NIMBYism: The role of place attachment and place identity in explaining place-protective action. Journal of Community $\&$ Applied Social Psychology, 19(6), $426-441$.

Firestone, J., and Kempton, W. (2007). Public opinion about large offshore wind power: Underlying factors. Energy Policy, 35(3), 1584-1598.

Hainmueller, J., Hopkins, D. J., and Yamamoto, T. (2014). Causal inference in conjoint analysis: Understanding multidimensional choices via stated preference experiments. Political Analysis, 22(1), 1-30.

Hirsh, R. F., and Sovacool, B. K. (2013). Wind turbines and invisible technology: Unarticulated reasons for local opposition to wind energy. Technology and Culture, 54(4), 705-734.

Jeong, G.-H., and Lowry, W. (2019). The polarisation of energy policy in the US Congress. Journal of Public Policy, 1-25. https://doi.org/10.1017/S0143814X19000175

Kane, J. V., and Barabas, J. (2019). No harm in checking: Using factual manipulation checks to assess attentiveness in experiments. American Journal of Political Science, 63(1), 234-249.

Klick, H., and Smith, E. R. (2010). Public understanding of and support for wind power in the United States. Renewable Energy, 35(7), 1585-1591.

Kohler, Florian, and Goebel, V. (2014). Areas with urban character 2012: Explanatory report. Neuchâtel: Federal Statistical Office. 
Kriesi, H., and Trechsel, A. H. (2008). The politics of Switzerland: Continuity and change in a consensus democracy. Cambridge: Cambridge Univesity Press.

Kuzemko, C. (2016). Energy depoliticisation in the UK: Destroying political capacity. British Journal of Politics and International Relations, 18(1), 107-124.

Leeper, T. J., Hobolt, S., and Tilley, J. (2019). Measuring subgroup preferences in conjoint experiments. Political Analysis. https://doi.org/10.1017/pan.2019.30

Mansfield, C., Van Houtven, G., and Huber, J. (2001). The efficiency of political mechanisms for siting nuisance facilities: Are opponents more likely to participate than supporters? Journal of Real Estate Finance and Economics, 22(2-3), 141-161.

Pasqualetti, M. J., Gipe, P., and Righter, R. W. (2002). Wind power in view: Energy landscapes in a crowded world. San Diego: Academic Press.

Sherren, K., Parkins, J. R., Owen, T., and Terashima, M. (2019). Does noticing energy infrastructure influence public support for energy development? Evidence from a national survey in Canada. Energy Research \& Social Science, 51, 176-186.

Stokes, L. C. (2016). Electoral backlash against climate policy: A natural experiment on retrospective voting and local resistance to public policy. American Journal of Political Science, 60(4), 958-974.

Wolsink, M. (2006). Invalid theory impedes our understanding: A critique on the persistence of the language of NIMBY. Transactions of the Institute of British Geographers, 31(1), 85-91.

Wolsink, M. (2007). Wind power implementation: The nature of public attitudes: Equity and fairness instead of "backyard motives". Renewable and Sustainable Energy Reviews, 11(6), $1188-1207$. 


\section{Appendix-The Survey}

1. Which canton and commune do you live in?

- Aargau [1] - Zürich [26]

- Aarau [1] - Zürich [2212]

2. How long have you been living in this canton?

- 0 - 111 years

3. Please indicate your gender.

- Male [1]

- Female $[2]$

- Other [3]

4. Please indicate your year of birth.

- $1908[111]-2001[18]$

[Additional questions for a separate study]

5. What is the highest level of education that you have already completed?

- Incomplete compulsory school/primary school [1]

- Compulsory school [2]

- Transitional educational programme [3]

- General training without maturity [4]

- Elementary vocational training or apprenticeship [5]

- Maturity or teacher training school [6]

- Post-secondary education, non tertiary [7]

- Vocational high school with federal or master certificate [8] 
- University of applied science, university, ETH [9]

- Doctorate, habilitation [10]

- Don’t know [9999]

6. How worried are you about climate change?

- Very worried [4]

- Somewhat worried [3]

- Not very worried [2]

- Not at all worried [1]

- Don't know [9999]

7. How interested are you in politics?

- Very interested [4]

- Somewhat interested [3]

- Not very interested [2]

- Not at all interested [1]

- Don't know [9999]

8. In politics people sometimes talk of 'left' and 'right'. Where would you place yourself on the scale below, where 0 means the left and 10 means the right?

- $0[0]-10[10]$

9. To increase the amount of electricity generated from renewable sources of energy, there are proposals to place wind turbines in the canton of [own / different canton], in landscapes similar to the one pictured below.

[Photograph with / without a wind turbine]

There has been a mixed reaction to these proposals. Some ['people' / 'political parties, 
such as the Social Democratic Party of Switzerland,'] support these proposals while other ['people' / 'political parties, such as the Swiss People's Party,'] oppose them.

How about you? Do you support or oppose these wind turbine proposals?

- Strongly support [5]

- Support [4]

- Neither support nor oppose [3]

- Oppose [2]

- Strongly oppose [1]

- Don’t know [9999]

10. [Randomly insert $a, b$, or $c]$

a. Which of the following best describes the landscape photograph that you have seen in the previous question?

- It included no wind turbines. [0/1, depending on the vignette]

- It included one wind turbine. [0/1, depending on the vignette]

- It included two wind turbines. [0]

- Don't know [0]

b. Which location was referenced in the text about wind turbines that you have read in the previous question? [Randomise the order of the answer categories, except 'Don't know']

- [own canton $][0 / 1$, depending on the vignette]

- $[$ different canton $][0 / 1$, depending on the vignette]

- $[$ another canton $][0]$

- Don't know [0]

c. According to the text about wind turbines that you have read in the previous screen, which one of the following actors have disagreements over wind turbine proposals? [Randomise the order of the answer categories, except 'Don't know'] 
- People [0/1, depending on the vignette]

- Political parties [0/1, depending on the vignette]

- Energy companies [0]

- Don't know [0]

11. The Swiss federal election is being held on 20 October 2019. How likely is that you will vote?

- Very likely [5]

- Fairly likely [4]

- Neither likely nor unlikely [3]

- Fairly unlikely [2]

- Very unlikely [1]

- Don't know [9999]

- I am not eligible to vote [-9999]

[Show if $q 11 !=-9999 ;$ randomise the order of questions; show both $q 12$ and $q 13$ ]

12. How likely is it that you will vote for the Social Democratic Party of Switzerland?

- Very likely [5]

- Fairly likely [4]

- Neither likely nor unlikely [3]

- Fairly unlikely [2]

- Very unlikely [1]

- Don't know [9999]

13. How likely is it that you will vote for the Swiss People's Party?

- Very likely [5]

- Fairly likely [4]

- Neither likely nor unlikely [3]

- Fairly unlikely [2] 
- Very unlikely [1]

- Don't know [9999]

[Additional questions for a separate study]

14. What is the gross annual income of your household? Please include all income of all persons who contribute to the maintenance. Count not only wages, but also any other income.

- Less than CHF 33,000 [1]

- $\mathrm{CHF} 33,000$ - CHF 48,999 [2]

- $\mathrm{CHF} 49,000$ - CHF 61,999 [3]

- $\mathrm{CHF} 62,000$ - CHF 74,999 [4]

- $\mathrm{CHF} 75,000$ - CHF 87,999 [5]

- CHF 88,000 - CHF 103,999 [6]

- CHF 104,000 - CHF 121,999 [7]

- CHF 122,000 - CHF 145,999 [8]

- CHF 146,000 - CHF 186,999 [9]

- CHF 187,000 or more [10]

- Don’t know [9999] 